\title{
The White-breasted Guineafowl Agelastes meleagrides in Taï National Park, Côte d'Ivoire
}

\author{
I. S. FRANCIS, N. PENFORD, M. E. GARTSHORE and A. JARAMILLO
}

\section{Summary}

The White-breasted Guineafowl Agelastes meleagrides, an endangered endemic bird of the Upper Guinea forests of West Africa, was studied in Taii National Park, south-west Côte d'Ivoire, from February 1989 to February 1991. Groups of guineafowl were followed, with notes made on behaviour, movements, diet and habitat; droppings were collected, photographs taken and sound recordings made.

There were 118 sightings of the birds, with 120 hours of direct observation. Average group size was 15.8 , and young birds were seen on 12 occasions in the months November to May. The birds prefer dry, closed-canopy forest, and avoid wet valley bottoms. They spend much of the day walking over the forest floor searching for food, scratching leaves noisily and uttering a fairly continuous quiet "twitter". Around $60 \%$ of each day is spent feeding, and the birds appear to eat mainly invertebrates. Intra-group aggression or chasing occurs with some frequency. Preening is also frequent, accounting for around $20 \%$ of the day. Alertness, walking and inactivity occur for short periods throughout the day. The birds roost in thin understorey trees, with group members spread over around $30 \times 30 \mathrm{~m}$.

The birds range over approximately $0.9 \mathrm{~km}^{2}$, and during the day follow a convoluted route. If one group encounters another, fierce inter-group aggression may ensue. Over much of Taï Forest, an average group of guineafowl is likely to consist of around 16 birds and range over approximately $1 \mathrm{~km}^{2}$. The population of the birds in Taï National Park may number perhaps 30,000-40,000 birds. The conservation of White-breasted Guineafowl will be best achieved through the protection of its remaining forest habitat and prevention of hunting.

La pintade à poitrine blanche Agelastes meleagrides, une espèce menacée d'oiseau endémique des forêts de Haute Guinée dans l'Ouest Africain, a été étudié dans le Parc National Taï, au sud-ouest de la Côte d'Ivoire, de février 1989 à février 1991. Des groupes de pintades ont été suivis, et des notes prises sur leur comportement, leurs mouvements, leur régime alimentaire et leur habitat; des fientes ont été recueillies, des photos prises et des sons enregistrés.

Ces oiseaux ont été vus 118 fois, représentant un total de 120 heures d'observation directe. La taille moyenne d'un groupe de pintades était de 15,8 individus, et de jeunes oiseaux ont été vus à 12 reprises pendant la période de novembre à mai. Ces oiseaux prefèrent des forêts sèches, à voûtes fermées, et évitent les fonds de vallées humides. Ils passent la majeure partie de la journée à marcher sur le sol de la forêt, cherchant leur nourriture, grattant bruyamment les feuilles et émettant un gazouillement tranquille, assez continu. Près de $60 \%$ de chaque journée sont consacrés à la recherche de l'alimentation, et ces oiseaux semblent se nourrir principalement $d^{\prime}$ invertébrés. Les agressions et les poursuites internes au groupe se produisent assez fréquemment. Le lissage des plumes est également fréquent et occupe à peu près $20 \%$ de la journée. L'état d'alerte, la 
marche et l'inactivité occupent de courtes périodes de temps tout au long de la journée. Ces oiseaux se perchent sur les arbres fins des sous-bois, les membres du groupe pouvant occuper une superficie d'environ $30 \times 30 \mathrm{~m}$.

L'aire de distribution de ces oiseaux couvre approximativement $0,9 \mathrm{~km}^{2}$ et pendant la journée ils suivent un itinéraire compliqué. Si un groupe en rencontre un autre, un combat féroce entre les deux groupes peut s'en suivre. Dans la majeure partie de la forêt Taï, un groupe moyen de pintades consiste en général de 16 oiseaux et occupe une superficie d'environ $1 \mathrm{~km}^{2}$. La population de ces oiseaux dans le Parc National Taï doit compter entre 30,000 et 40,000 individus. La meilleure façon de protéger la pintade à poitrine blanche est de préserver ce qu'il reste de son habitat forestier et d'empêcher la chasse de cette espèce.

\section{Introduction}

Taï National Park is situated in south-west Côte d'Ivoire (Figure 1) and comprises some 340 , ooo ha of primary tropical lowland forest, together with a 66,000 ha peripheral zone which has undergone some partial logging in the past. As a key area for the conservation of West African rainforest, it has been designated a UNESCO Biosphere Reserve and a World Heritage Site. Moreover, it is considered the largest and best preserved area of Upper Guinean forest, and critical for the conservation of Upper Guinea rainforest endemic birds (Collar and Stuart 1988, Allport 1991). Of the 247 forest bird species that occur within the Upper Guinea forest block, 14 are endemic and seven are near-endemic (Allport et al. 1989).

The White-breasted Guineafowl Agelastes meleagrides is one of the endemics found in the Upper Guinea forest. The large-scale loss of West African rainforests is thought to have led to a drastic decline in its population, and it is now considered to be one of the most threatened birds in continental Africa (Collar and Stuart 1985). The rate of forest destruction west of the Dahomey Gap is so severe (currently around 5\% per annum: Davies 1987) that any bird species endemic to primary forest in this area must be considered gravely at risk. Available evidence (Collar and Stuart 1985, Allport 1991) suggests that the strongholds of this species are south-east Liberia and south-west Côte d'Ivoire, although White-breasted Guineafowl also occur in Sierra Leone and Ghana, and possibly Guinea (Allport 1991). In Cote d'Ivoire, the species is probably now found only in Taï National Park.

\section{Previous studies of the species}

This study was part of Phases IIb and III of the Taï Avifaunal Survey, which built on previous work undertaken during Phase I of the survey in 1989 (Gartshore 1989), when several observations of the species were made and it was recommended that further studies be carried out.

Other work on White-breasted Guineafowl has been very limited. Bechinger (1964) provided some observations of wild and captive birds in Côte d'Ivoire, but since then the only studies have been those of Taylor (1988) in Liberia and Allport et al. (1989) in Gola Forest, Sierra Leone. Other sightings and anecdotal records come from Ghana, Liberia and Sierra Leone, but most are old. They are summarized in Collar and Stuart (1985) and Allport (1991). 


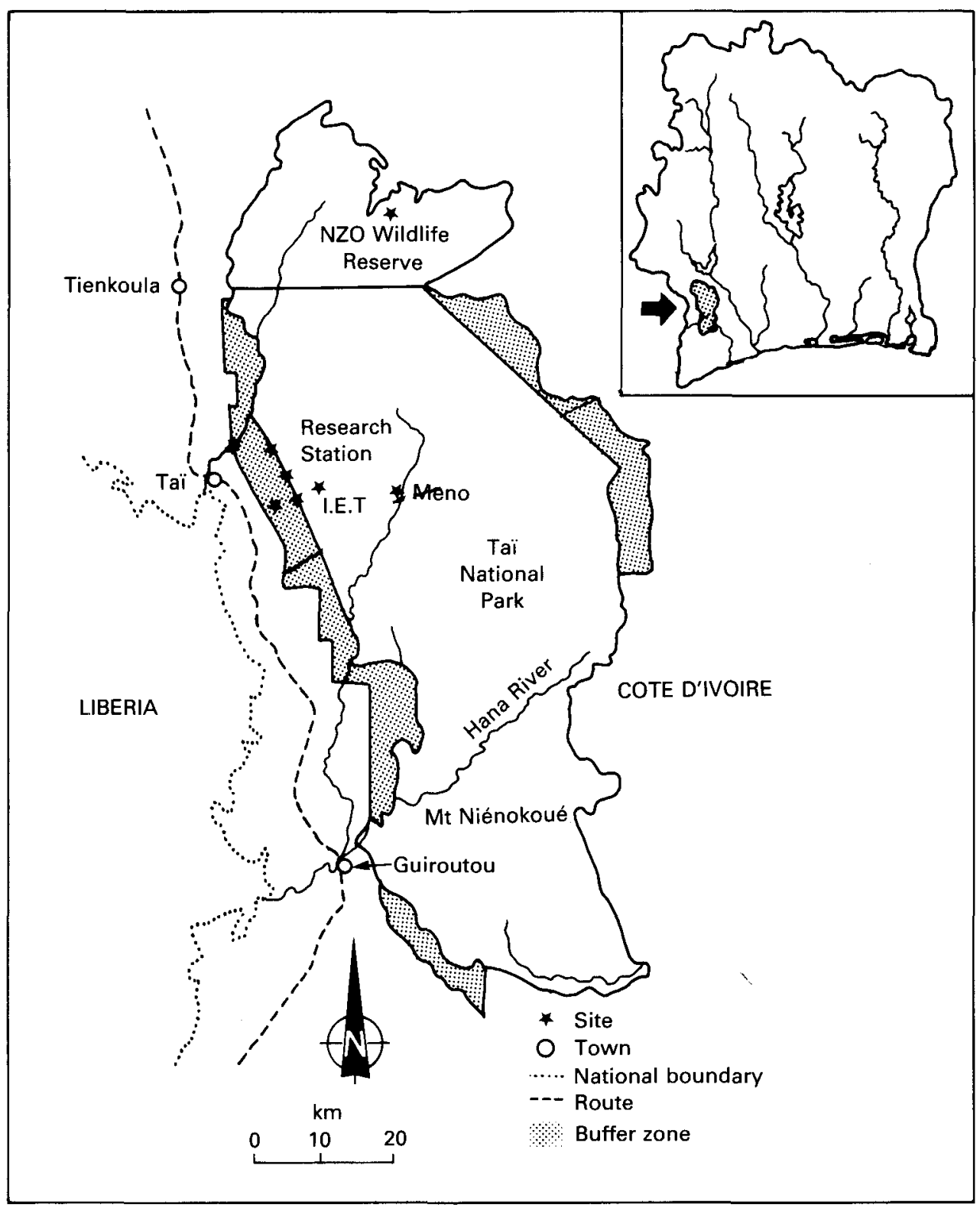

Figure 1. Taï National Park and its position within Côte d'Ivoire.

\section{Methods}

Dates of study and observer effort

The study was carried out principally during the periods 21 May to 10 July 1990 and 12 November 1990 to 18 February 1991, and incorporates additional observations from January to April 1989 (Gartshore 1989) and December 1989 to May 1990 (Phases I and IIa of the Taï Avifaunal Survey). Reference is also made to 
some sightings made by other observers outside the phases of the survey. During Phase III of the study, 616 hours of observer effort was expended either searching for, or watching, the guineafowl. The two main study periods may be characterized as falling into "wet season" (May to July - Phase IIb) and dry season (December to February - Phase III). Meteorological information on the area is in Casenave et al. (1990) and UNESCO (1984).

\section{Main study methods}

The most important source of information was direct visual observations made whilst quietly following groups of guineafowl. However, in order to find the birds, a great deal of search effort was required, in the form of quiet walks through the forest punctuated by bouts of listening from a fixed position for up to one hour. Frequently, search effort was concentrated in areas of recent sightings, but this was not always successful. We often used paths and transects on a grid system, since walking through dense forest was too noisy to detect birds easily. Once located, we attempted to follow the birds as closely as possible without influencing their behaviour greatly. Most of the time this was possible, though on occasions we either alarmed them or made them walk faster than they would have done. We tried to follow them for as long as possible, and on five occasions followed them to roost, revisiting the roost before dawn the following morning on two occasions. Our field methods may be summarized as follows:

(i) We made detailed notes on behaviour, calls, feeding and any other event during each period of contact. These were transcribed onto a standard recording form.

(ii) Detailed notes of the forest habitat were made in an effort to discover favoured feeding areas.

(iii) The direction of each movement of the guineafowl in degrees, the estimated distance walked and the time were recorded. These were later plotted to scale.

(iv) Timed observations of individual behaviour were made whenever possible, to produce detailed time budgets. However, this was difficult to carry out, owing to the almost constant movement of the flock and the dense forest floor vegetation. These factors meant that it was almost impossible to watch any individual bird for longer than a few minutes, and often the period of clear view was measured in seconds. In addition, it was impossible to view all the birds in the flock at once, to undertake whole group scans.

(v) Droppings were collected from feeding areas. The fresh weight of each was recorded immediately after collection, and then each dropping was preserved in alcohol. Droppings were sometimes difficult to find, and the most productive places were areas where birds had fed for perhaps 20 minutes. Notes were also made on the amount of leaf-htter disturbance in feeding areas.

(vi) We made tape-recordings of calls on several occasions, using a Sony Walkman Professional and a microphone. Most guineafowl calls are faint, and it proved difficult to obtain clearly audible recordings above the background noise of insects and other bird calls. 
(vii) We took a total of 52 photographs, of which approximately 20 were of reasonable quality (see plates 1 to 5 ). We also took photographs of roost trees and feeding scrapes. Some of the photographs have been lodged with ICBP and World Pheasant Association.

To help in our collection of information, we periodically employed a local man (for 35 days in total), to allow us to cover more ground whilst searching, to collect droppings, and to help in following groups for long periods. Finally, to expand the geographical area of our study, we produced standard forms in French and English. These were given to all researchers and station staff to record details of any casual sightings they made whilst working in the forest.

\section{Results}

\section{Contact hours and presentation of information}

During the two main phases of the study, a total of 120 observer hours was spent watching guineafowl, with approximately 20 hours between May and July 1990, and 100 hours between November 1990 and February 1991. In this latter period, the 100 hours represent $16 \%$ of the total time spent either looking for, or watching, the birds. This means that for every day spent watching the guineafowl, approximately five days were spent searching. In addition to our own sightings, numerous other records were provided by station staff and researchers. Table 1 lists all guineafowl sightings in chronological order in all phases of the study, with some additional sightings by other researchers. In total, from February 1989 to February 1991, we have records of 118 sightings of White-breasted Guineafowl flocks in Taï Forest, of which 59 provided definite counts of all the individuals in the group.

The information collected during our study is divided into a number of sections below. Details of the methods and data summary and presentation are contained in each section where relevant. An attempt is made to relate our findings to previous studies in the Discussion.

\section{General summary of detection and behaviour}

White-breasted Guineafowl move around the forest floor in groups, walking slowly whilst scratching leaves noisily. They utter a quiet "twitter" as they move. This behaviour accounts for much of each day. They cover around $1 \mathrm{~km}$ per day, though often in a convoluted pattern, such that they may end up only a short distance from where they start out. Their typical contact calls and leaf scuffing are audible for around $30 \mathrm{~m}$, though other calls are louder. This behaviour, together with the spacing of groups, means that it is possible to walk through the forest for a whole day without finding a group, since they need to be within around $40 \mathrm{~m}$ to be detectable. Conversely, their slow, meandering mode of foraging means that observers doing other tasks (watching chimpanzees, taking soil samples, etc.) may encounter them by chance quite frequently. Thus, casual records were important as ways of locating groups in the general area of our study. 


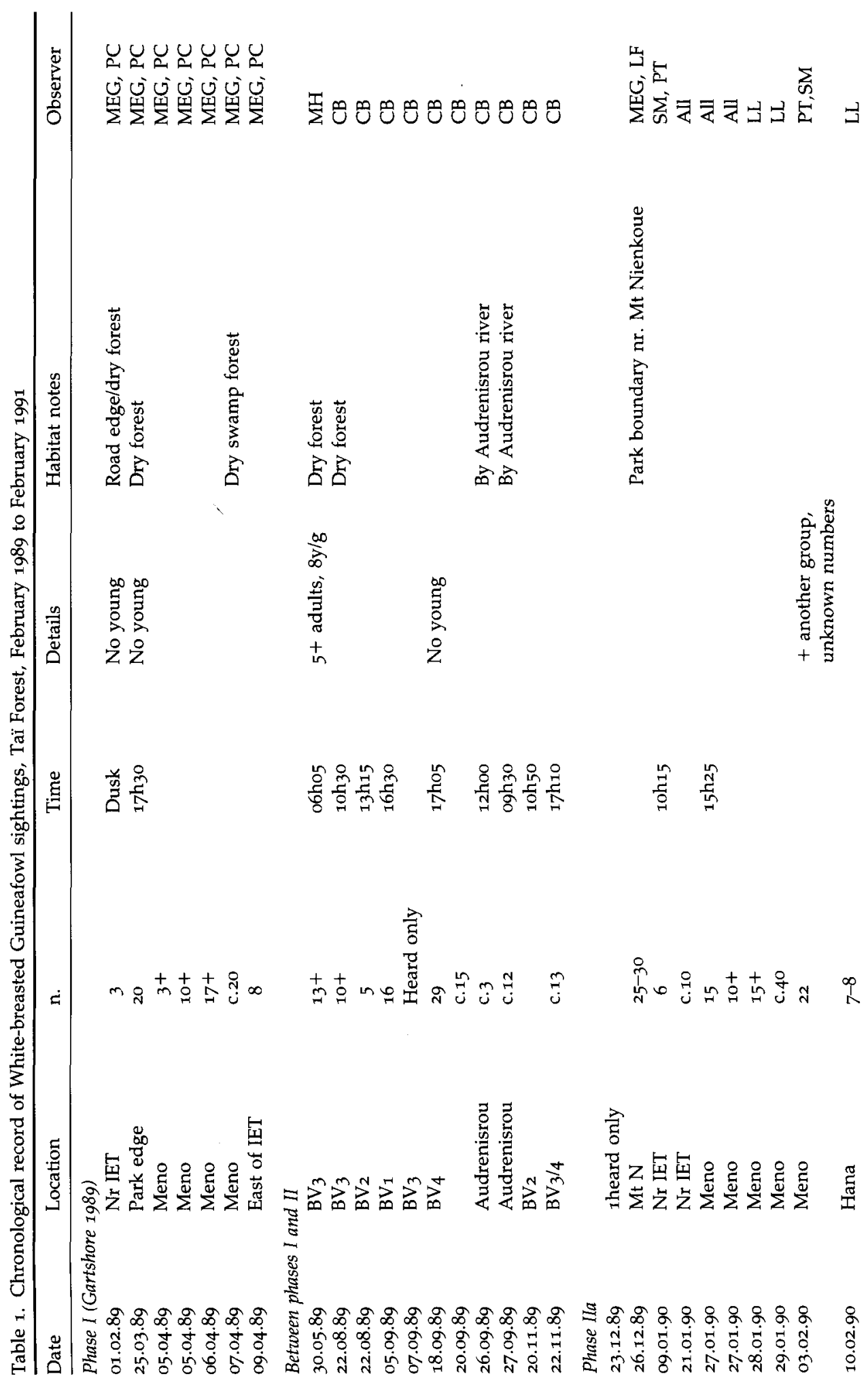




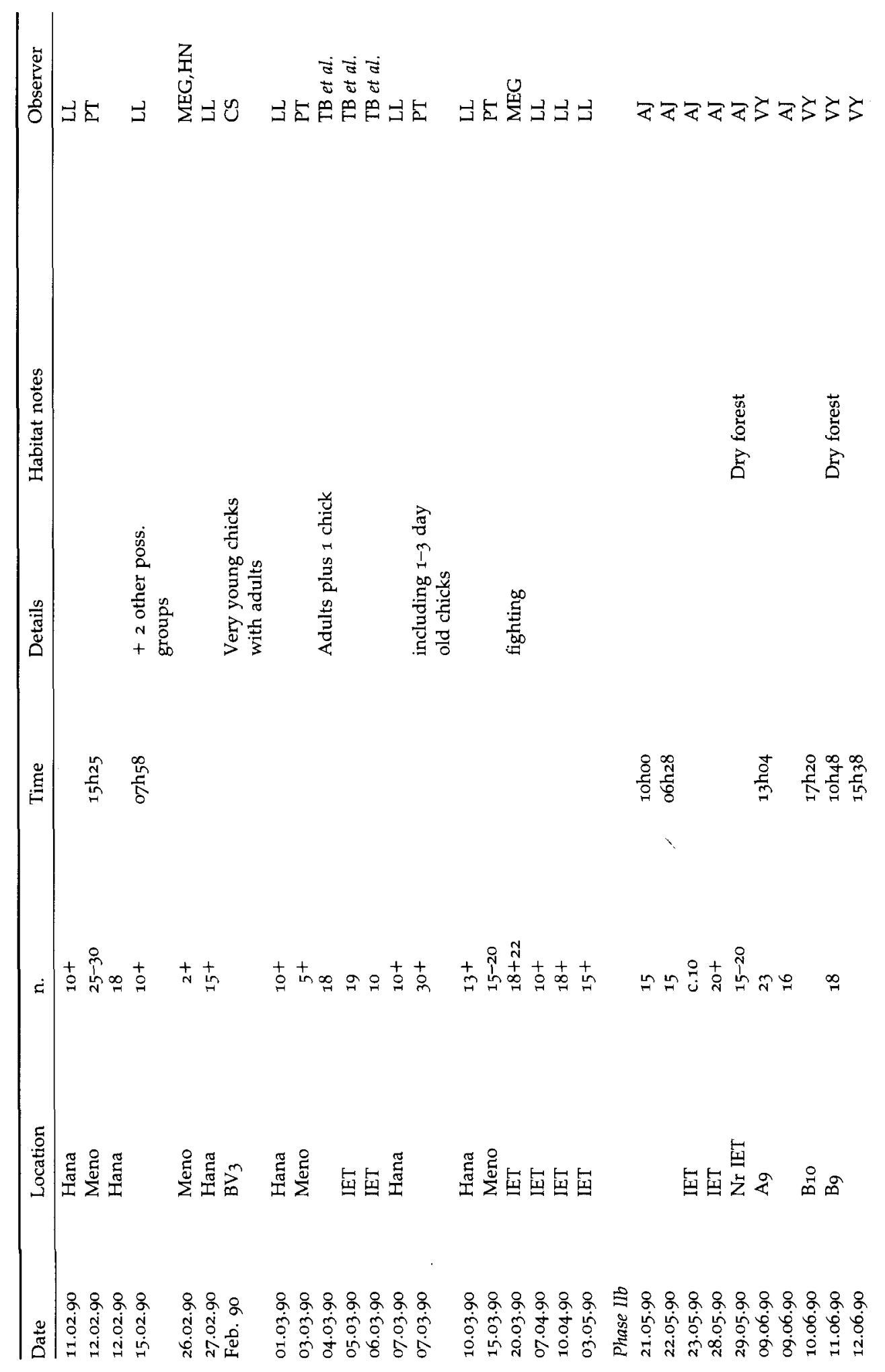




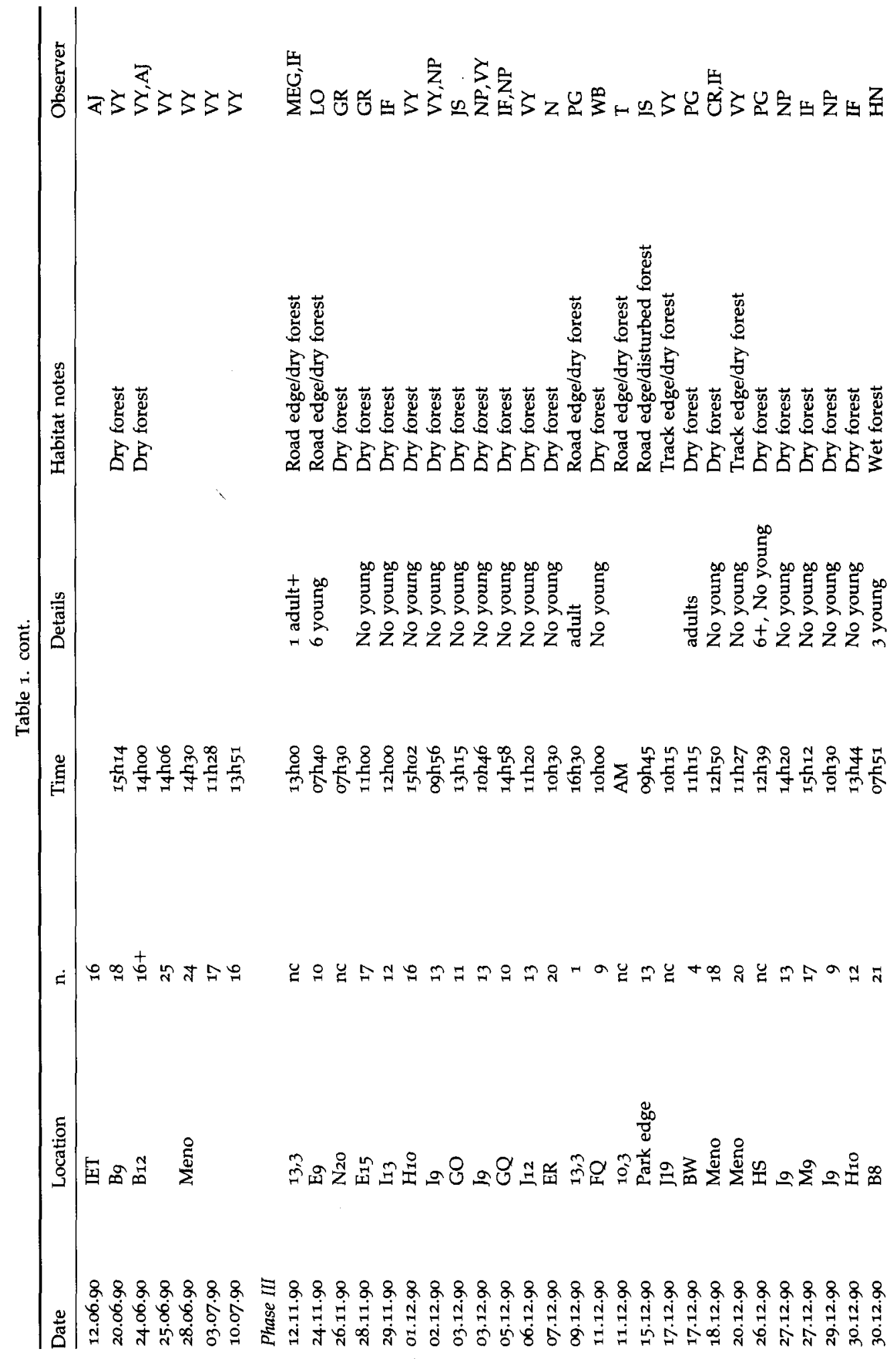




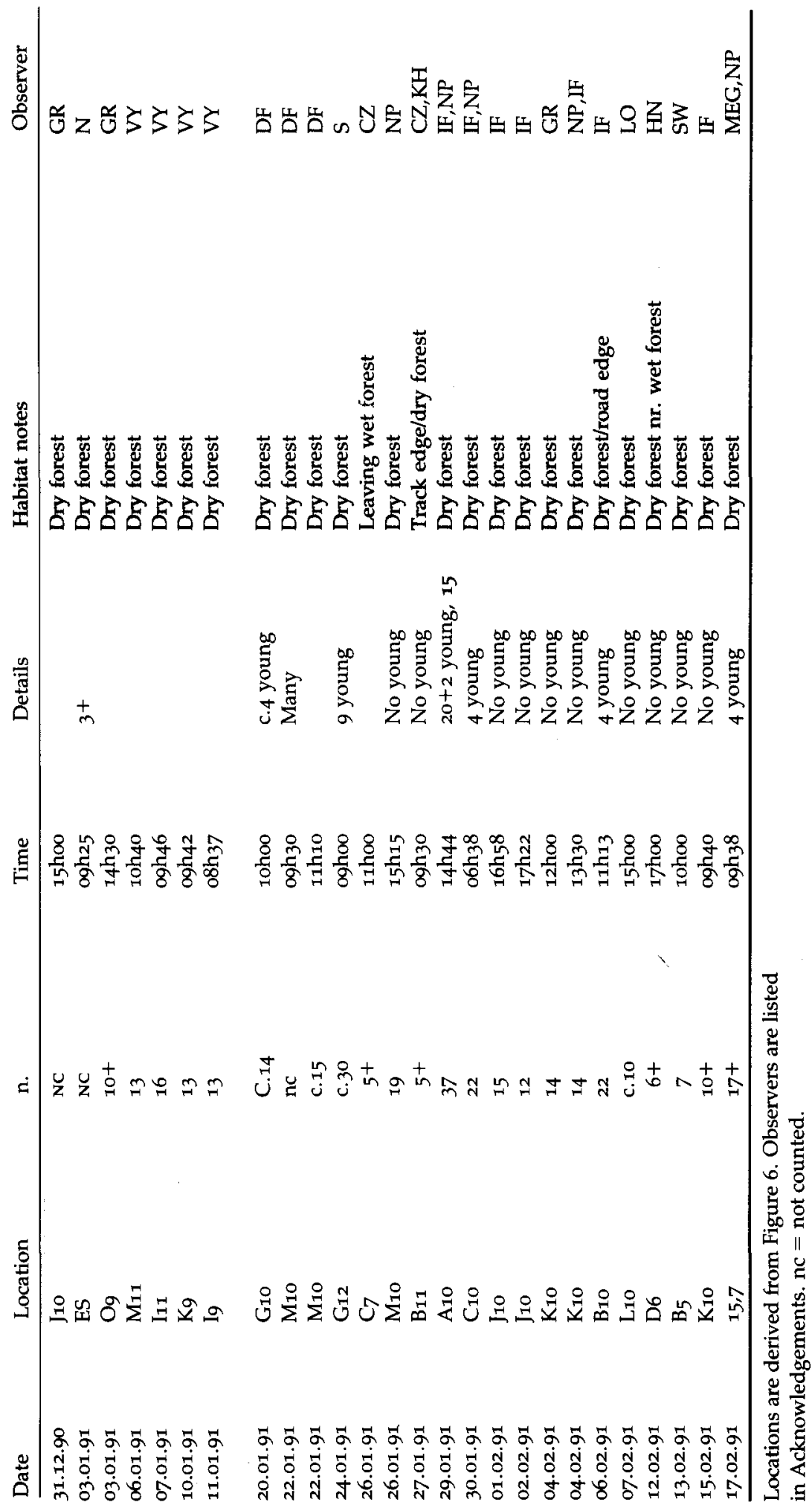




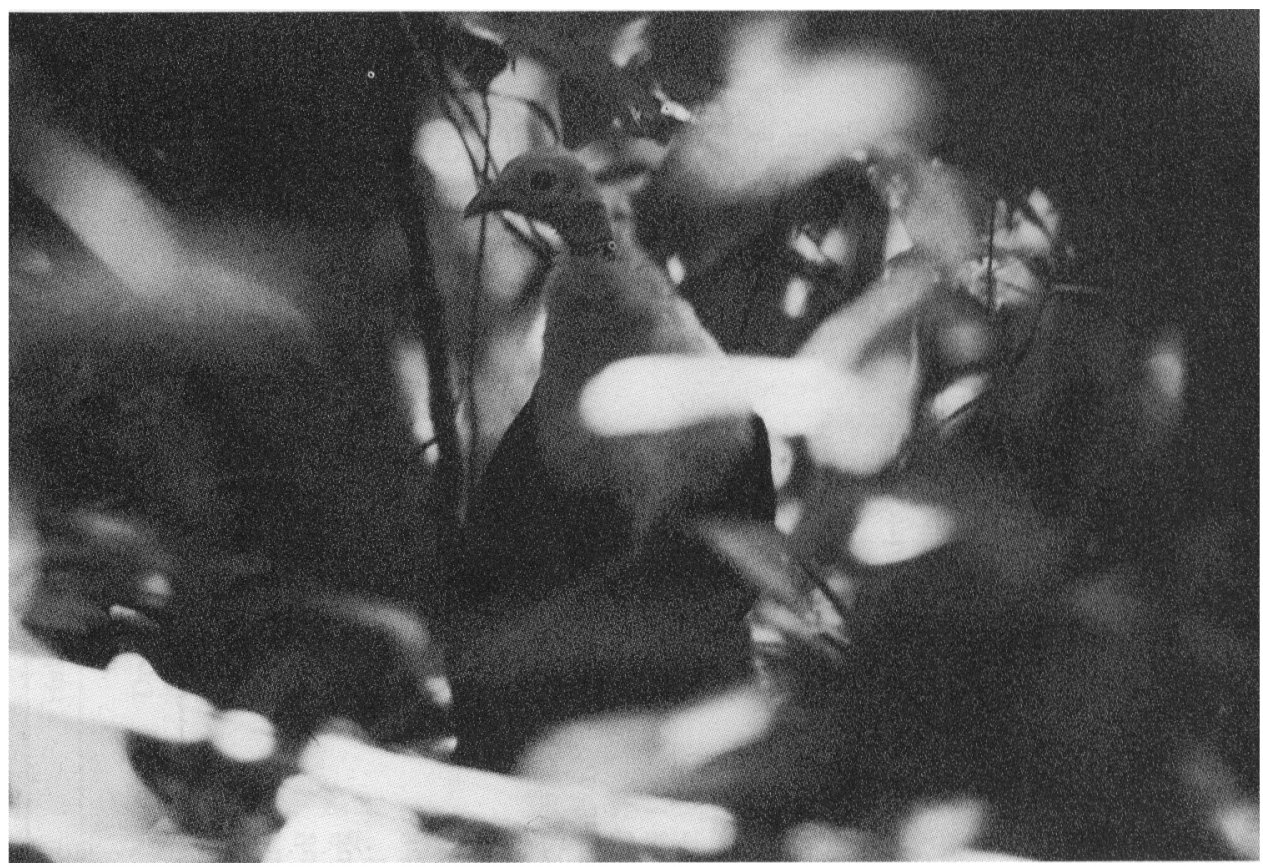

Plate 1. The White-breasted Guineafowl Agelastes meleagrides.

Once located, the birds are generally very tame, allowing an observer to approach them frequently to $10 \mathrm{~m}$ and often $5 \mathrm{~m}$ without apparently influencing their behaviour. Needless to say, however, quiet movement and muted clothing are essential. Although it is generally impossible to walk through the forest quietly, owing to the dense layer of dry leaves and twigs, the guineafowl seem not to be too perturbed by rustling and twig breaking, probably because of their own noisy mode of foraging and the fact that branches frequently fall from the canopy throughout the day. If the observer remains still, the birds may turn and approach within $3 \mathrm{~m}$ before becoming cautious. However, even at this distance, the density of saplings in many areas makes it frustratingly difficult to obtain a clear, uninterrupted view for any length of time (Plate 1 shows a typical view). Sometimes, the birds become rather silent, and if this coincides with dense undergrowth, it is possible to lose the birds. This happened on several occasions.

The birds may spend part of each day preening, or chasing each other, but most of the time the slow, feeding walk predominates. They may stay in one place for up to an hour at times, but generally continue moving.

\section{Feeding behaviour and diet}

Feeding behaviour The usual feeding method is a slow walk with frequent stops, often lasting several minutes. During the stops, the birds scratch at the leaf cover of the forest floor, around 2-3 times with each foot in turn, punctuated by peering intently to look for food, and pecks at the food if unearthed. The mode of feeding resembles that of domestic chickens, but differs in detail in that they look whilst scratching rather than afterwards. They are slightly crouched over 


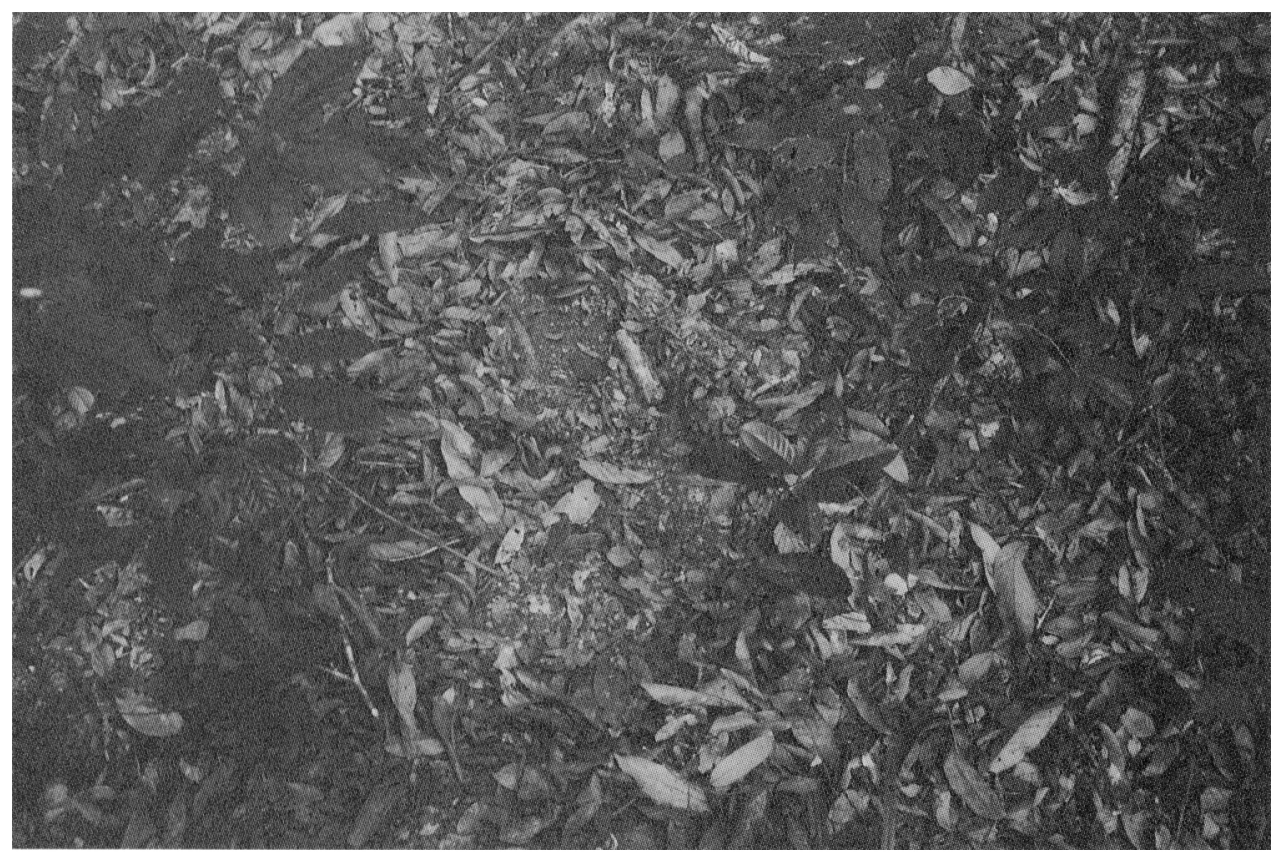

Plate 2. Feeding scrapes.

whilst feeding, and make long scratches with their rather long legs. There are frequently several scratching bouts before one is successful. When feeding on the scraped areas, peck rates average around 4.5 per to seconds of feeding (range 1-10 per 1o seconds, depending on the abundance of food). Sometimes one bird finds food in abundance, and calls with an excited twitter or whistle, and other birds run a short distance to feed with it. The spacing of birds whilst feeding is highly variable, ranging from several birds foraging within a few centimetres of each other to single birds foraging up to $10 \mathrm{~m}$ from the others. Whilst foraging, the noise of leaf-scuffing is very loud, especially in the dry season, and is audible perhaps $30 \mathrm{~m}$ away.

Scratched areas consist of bare soil with leaves pushed to round the edges and some small roots revealed. Some feeding areas are very obviously disturbed, with many scrapes, but others are not heavily worked. Typical feeding scrapes average $32 \times 17 \mathrm{~cm}$ or $544 \mathrm{~cm}^{2}(n=16)$, ranging from $5 \times 5 \mathrm{~cm}$ to $150 \times 20 \mathrm{~cm}$ where several birds have fed together. Feeding areas are sometimes concentrated round the bases of small saplings. Plate 2 shows a typical feeding scrape. On several occasions, the birds were observed feeding at the same spot for quite long periods; the longest was 105 minutes on 6 February 1991.

On 29 November 1990, during the wet season, birds were seen to forage by moving rather more quickly through the forest, pecking at insects on vegetation in a rather more opportunistic way, and they hardly scratched the ground at all in two hours. This feeding behaviour was only noted once.

Diet: observations We found it very difficult to observe directly what the guineafowl eat. The prey items are very small, quickly swallowed, and few are large enough to be identified confidently. Most items that could at least be seen 
appeared to be invertebrates, though it is possible that small seeds were also eaten. The most frequent prey appeared to be termites, and on some occasions termites were found on feeding areas after the birds had left, though there was no apparent association between the birds and termite mounds. Other invertebrates which the guineafowl ate were ants, crickets, millipedes and worms (the latter in a wet stream valley, where two birds fought over a worm and pulled it in half). On 5 February 1991, birds were observed feeding for some time around dense heaps of fallen fruit under a tree. However, it seemed that they were feeding on large numbers of fruit flies and other insects, and there was little evidence of the fruit itself being eaten.

Diet: analysis of faeces An analysis of faecal material from White-breasted Guineafowl was undertaken on samples collected in July 1990 and between December 1990 and February 1991 (J. V. Beer, S. Moreby in litt. 1991). Invertebrate material predominated, consisting of many unidentifiable fragments, although beetle larvae (Chrysomelidae), ants and, to a lesser degree, spiders were noted. Only one tapeworm egg was seen and no oocysts. Bacterial numbers were low microscopically, i.e. there was no evidence of enteric disease. The relatively scarce plant material was so finely comminuted that few large pieces were seen and such items as stomata and xylem cells were rare. Grit was present in most samples.

There seemed to be no difference in diet between the samples for July and December-February, although the former were very few. Ten Crested Guineafowl Guttera pucherani samples from August 1990 were also analysed. Their composition differed little from the White-breasted Guineafowl samples, largely consisting of invertebrate material, mostly (Chrysomelid) beetle larvae, adult beetles, ants, flies, unidentified Hymenoptera and also one spider. Fungal hyphae were noted in one sample, presumably plant pathogens or saprophytes. The presence of termites in the diet of both species remains a possibility, but comparison of unidentified fragments with appropriate reference material is necessary (S. Moresby pers. comm.).

\section{Other behaviour}

Walking The usual mode of feeding incorporates a slow walk of a few decimetres between scratching sites, but more rapid and protracted walking is also quite frequent, such as when moving between feeding sites, when crossing tracks or when alarmed. The head is usually held up, though not extremely so, and sometimes moves back and forth whilst walking. The body is generally fairly horizontal, giving the bird quite an elongated appearance (Plate 3). Speed of walking may be quite high, up to $45 \mathrm{~m}$ per minute, though usually it is much less than this. Birds often walk in a line, especially when crossing tracks, and this may offer the best opportunity to count the flock.

Intra-group spacing, chasing and flying Guineafowl flocks vary in their intragroup spacing according to circumstance. They are often very closely spaced when feeding or preening, and during the day groups disperse, then cluster frequently. Birds may stand or feed as close as $20 \mathrm{~cm}$ apart, then whilst walking 


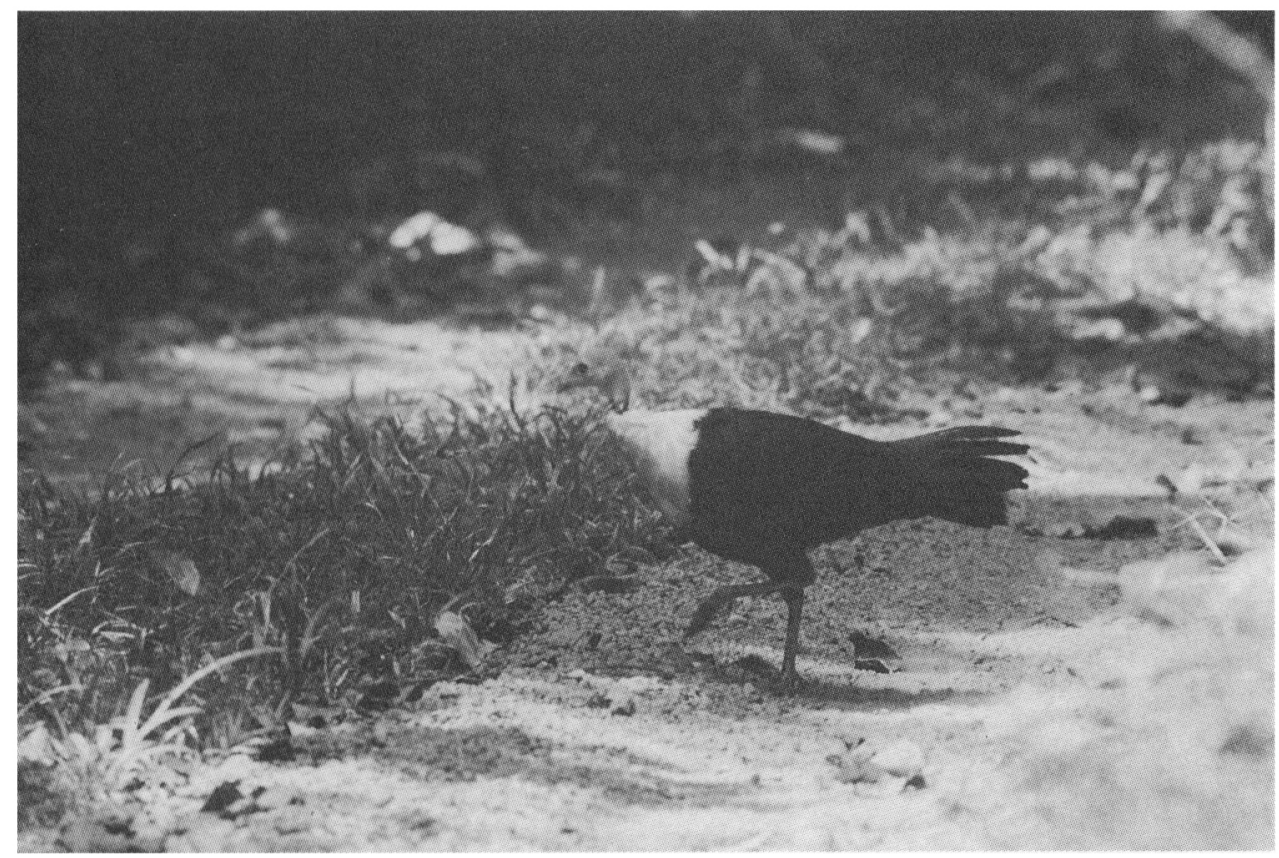

Plate 3. White-breasted Guineafowl.

they may spread over a wide area, such as $20 \times 20 \mathrm{~m}$, with individual birds $3 \mathrm{~m}$ or more apart. Usually, though, most birds are within a 3-4 $\mathrm{m}$ spread, with some outlying individuals, such that one may be left behind as the group moves off. Sometimes, one group may split into two or more subgroups, several or even tens of metres apart, and feed separately for a while. The most extreme example of this was noted on 29 January 1991, when a group of 22 split for over one hour, and fed up to $70 \mathrm{~m}$ apart. They then regrouped towards roosting time. The birds appear to roost separately, dispersed over perhaps $30 \times 30 \mathrm{~m}$ (see below).

Much of the time there is little aggression within groups, with birds feeding quietly close to each other. However, intra-group aggression or chasing was observed on numerous occasions, and there seemed to be a tendency for it to occur more in the larger groups. No clear reasons were seen, but frequently birds would chase each other with wing fluttering and excited, noisy twittering, cheeping and trilling. These chases usually involved two or three birds. Many times the chase led to birds flying up into the trees, up to $6 \mathrm{~m}$ high, where they remained for anything up to 22 minutes. On 18 February 1991, during $7 \mathrm{~h} 37$ min. of observation, birds flew into trees at least 24 times after being chased. Other aggression was seen once when two birds fought over a worm, and once when one bird was in the way of another and was pecked. On another occasion, one group of birds remained quite aggressive within the group, with much chasing and flying, for a whole afternoon following an aggressive encounter with another group (see below). Some of these chases described above are undoubtedly aggressive, but others may be related to courtship or pair bonding. A possible courtship display was seen on one occasion when one bird walked an S-shaped pattern in front of another which was feeding; much of the rest of the 
time many birds were chasing each other into trees (18 February, described above).

The guineafowl also fly on other occasions. Often, when startled by the observer, they will flutter, making alarm trills, a short distance into cover. On two occasions, the whole group flew in turn $10-15 \mathrm{~m}$ across a stream and a steep-sided river valley. On another occasion, an African Goshawk Accipiter tachiro flew over, which prompted panic and some birds flew into trees. On 26 December 1990, the guineafowl also flew in alarm as young chimpanzees Pan troglodytes chased them (P. Gagneux and P. Marchesi pers. comm.). Finally, they roost in trees, and readily fly up to and down from perches, and also between them (see below). In flight, the birds are quite long-tailed, appear all black and do not seem to be particularly ungainly, sometimes flying high into the trees.

Preening This can occur at any time of day, though prolonged bouts of preening are more frequent in the afternoon. Sometimes birds may spend many minutes preening; this may involve the whole group, or part of the group whilst others feed, and may be carried out standing or sitting. The use of the oil gland at the base of the tail was seen on two occasions, and once (3 December 1990) ants appeared to be used. Brief mutual preening, possibly involving pairs, was noted on five occasions.

Alertness The birds spend short periods alert and motionless, with head held up or with neck stretched, head up and the whole body almost vertical. This often happens for a short period when they become aware of the observer. Sometimes, only one bird does this whilst the others continue to feed, but the alert bird does not call to indicate danger to the others. At times, birds investigate a novel source of danger (such as the observer) by walking towards it, with head up.

Inter-group behaviour Two instances of inter-group interaction were observed. On 20 March 1990, a group of 18 feeding birds suddenly ran through the forest and began to fight with another group. No less than 40 birds were involved in this skirmish. Pairs of individuals attacked each other like game cocks, flying into the air and thumping each other with their feet. There were so many birds together that fighting between two could not continue without interference from others. Soon several birds were panting and lines of $2-6$ birds would retreat to preen or scratch in displacement activity. At least half of each flock was engaged in resting and preening while the other half fought in a kind of central arena. Fighting stopped for a while, with resting birds moving into the centre, calling and stretching their necks; then it broke out again. Exhausted birds retreated, panting, to rest, and also to keep watch for predators. After 27 minutes, the groups moved in one direction, there were further brief skirmishes, then $19^{+}$ birds ran back the other way, making a 3-4 note descending whistle, dying away to a faint croak like Crested Guineafowl. At 16h10, parts of the two groups appeared to meet again, with brief bouts of chasing, and twice birds flew into trees.

On 29 January 1991, a group of 22 birds met another group of 15 . This led to much chasing, fighting and calling, with birds exploding into flight in all direc- 


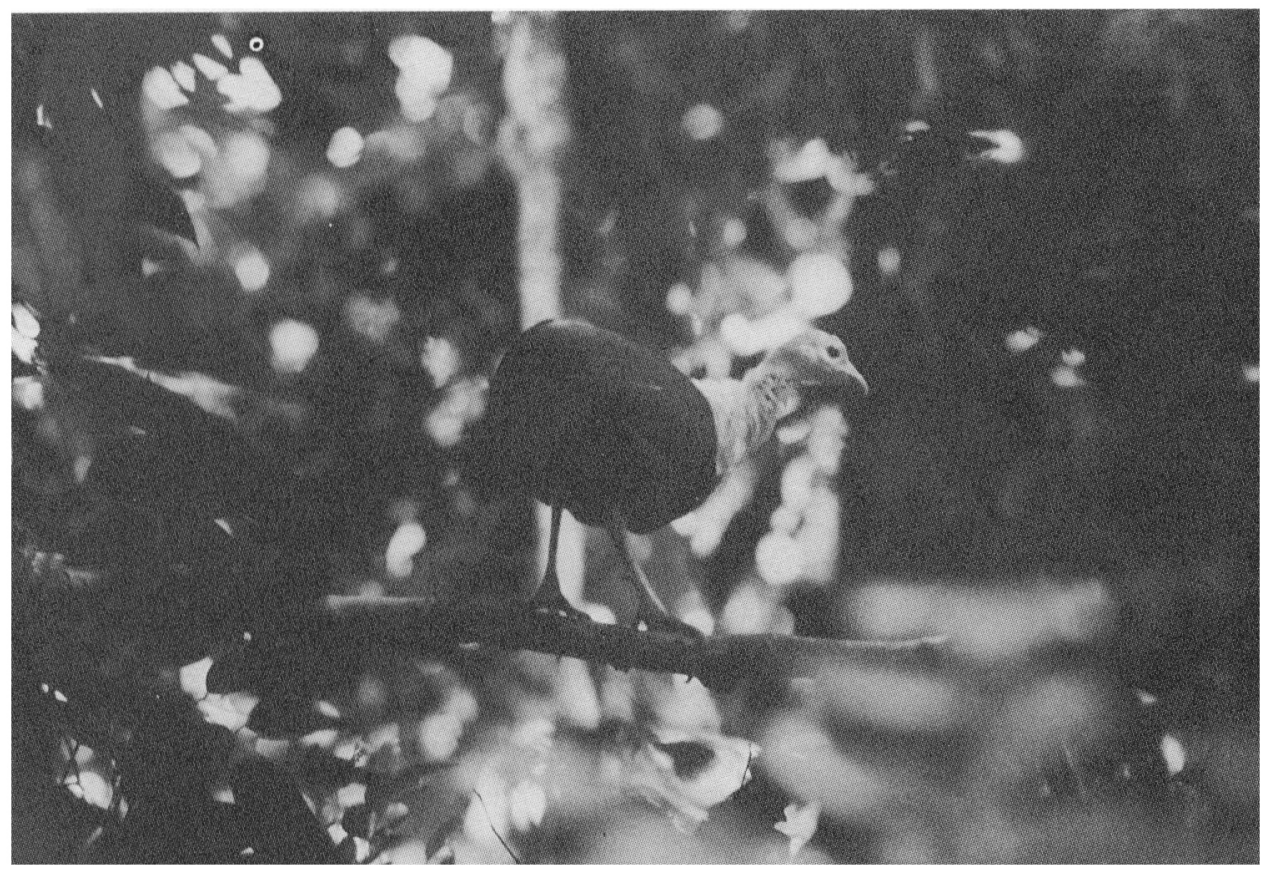

Plate 4. Many birds flew into trees, remaining there for several minutes, usually at a height of about $10 \mathrm{~m}$.

tions. Birds were seen to flutter against each other, beating wings, though no further details of fighting were observed. This encounter lasted for around 10 minutes, though most of it was over in one minute. Many birds flew into trees, where some remained for several minutes at heights of between 3 and $20 \mathrm{~m}$, though mainly around $10 \mathrm{~m}$ (Plate 4). Several birds made fast, aggressive, steep dives down at other birds from these perches. The two groups eventually separated, although the details of this were impossible to see.

Roosting Groups of guineafowl were followed to roost on five occasions, and followed from the same roost the following morning on two occasions. On 21 May 1990, the birds flew to roost at $18 \mathrm{~h} 24$, and left the roost the following morning between o6h3o and o6h39. On 11 June, they went to roost at $18 \mathrm{~h} 35$. Similar times were recorded in January/February, when birds went to roost between $18 \mathrm{~h} 20$ and $18 \mathrm{~h} 35$ on 29 February 1991, descending from roost the following day around o6h5o. On 1 and 2 February, a different group went to roost at $18 \mathrm{~h} 22-18 \mathrm{~h} 34$ and $18 \mathrm{~h}_{27}-18 \mathrm{~h} 40$ respectively. At this time it is still reasonably light, and the birds will fly from their perches if approached too closely. The birds frequently call before they fly to roost, during their flights and afterwards in the trees, twittering for five minutes, though descents in the morning are more silent. The twittering contact note, whistling muster notes and harsh guttural call are made (see below). On 29 January 1991, roosting was preceded by much chasing and calling, with some "trial" flights and descents; this was not the case on other occasions. On 21 May, birds were seen to fly up to $4-6 \mathrm{~m}$ initially, then higher in a second flight. On other occasions, movement between 


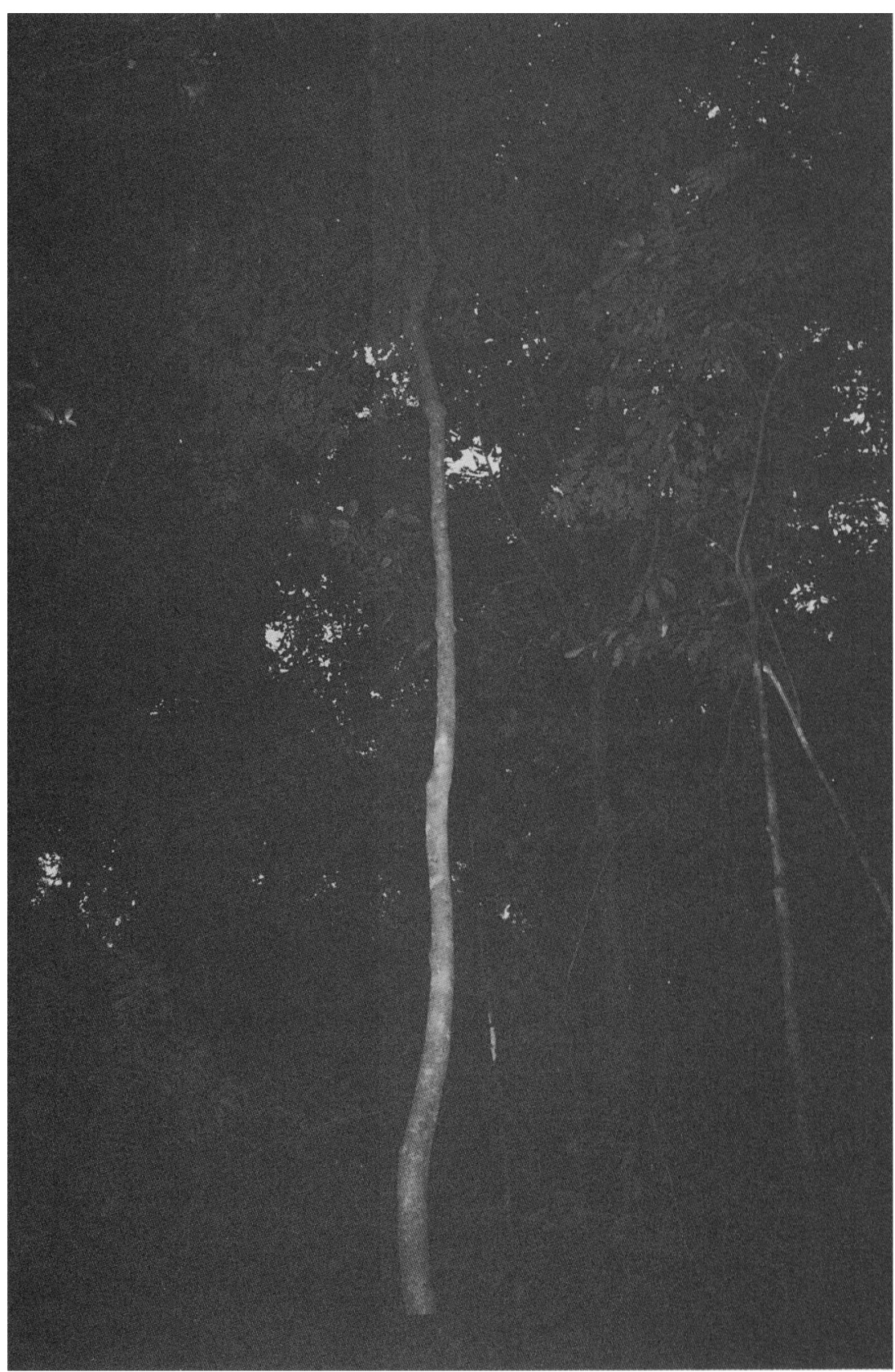

Plate 5. Roost tree.

perches was noted before the birds settled down, and birds frequently walk around on their roost perches. On 2 February, roosting occurred a little later, and was possibly deterred by a troupe of red colobus monkeys Colobus badius which moved overhead.

The birds roost 6-15 $\mathrm{m}$ up in thin, shrubby, understorey trees, not in large 
trees. One roost tree was $8 \mathrm{~cm}$ in diameter at breast height, reaching $9 \mathrm{~m}$, with a thin spreading crown. The actual roost perch was $c .1 .5 \mathrm{~cm}$ in diameter at $8 \mathrm{~m}$ height (Plate 5). The roosts usually cover an area perhaps as large as $30 \times 30 \mathrm{~m}$, with birds roosting singly in different trees in most cases. The guineafowl appear to roost opportunistically, wherever they finish the day. At none of the roost sites was there any evidence of regular or prolonged use, such as large amounts of droppings. On two occasions, roosts used the previous night were checked and no birds were present in the area. However, on 1 and 2 February 1991, the same group was followed to roost on two consecutive days, and although it roosted in different locations these were only about $30 \mathrm{~m}$ apart.

\section{Calls}

Although the call of the White-breasted Guineafowl is described by MackworthPraed and Grant (1970) as a "low, deep kok-kok", in fact the species has a range of calls, none of which can be described as such. We differentiate below eight distinct calls. We made tape-recordings of several of these (indicated by ${ }^{*}$ ); copies have been deposited with BLOWS, ICBP and WPA. It is noteworthy that, in the dry season at least, the loudest noise (and most reliable way of locating the birds) is that of leaf-scuffing as they feed; this is frequently much more obvious than their usual vocalizations.

(1) The most frequent call is a rapid, high-pitched, light, slightly metallic "twitter", uttered fairly constantly whilst walking and feeding, by many of the birds in the flock. This is audible up to $30 \mathrm{~m}$ away, and varies in its tempo, though not usually in pitch. (2) This rapid twitter may become louder, slower and more deliberate: a "tiss-tiss-tiss", slightly like day-old chicks. (3) A mustering call, often made by only one bird: a loud, even-pitched whistle, sometimes increasing in volume, occasionally answered by others. (4) A variant of call 3, a descending whistling trill, like the Grey-headed Bristlebill Bleda canicapilla; both call 3 and call 4 may elicit call 1 as a response from other birds. (5) A rather shrill squeak when startled. (6) $)^{*}$ "lost" call made by a bird separated from the group: a repeated, single, slightly descending, slow mournful whistle, quite flute-like, uttered whilst walking. (7) An agitated rapid metallic trill uttered whilst fighting. (8)* A harsh guttural grating call, similar to Crested Guineafowl, made when flying to roost or when disturbed.

Call $I$ is by far the commonest. The others have more specific uses, and may not be given by all the birds in a group. Several times during the day there may be periods when the birds are silent, usually when stationary, but also when walking rapidly, especially when a group makes a deliberate move from a feeding area. At roost, calls 1 and 8 may be made from the trees.

\section{Breeding and young}

The nest of the White-breasted Guineafowl has never been found by ornithologists (Collar and Stuart 1985, Crowe 1985, G. Allport pers. comm. 1991), though young birds have been seen by several previous researchers (e.g. Allport et al. 1989). In Taii, young birds were seen on 12 occasions between May 1989 and February 1991 (Table 2). Young were seen within the period 24 November to 30 
Table 2. Sightings of White-breasted Guineafowl with young, Taï National Park, May 1989 to February 1991

\begin{tabular}{|c|c|c|c|}
\hline Date & Details & Location & Observer \\
\hline 30.05 .89 & $5+$ adults with 8 young $(+10 \mathrm{~cm})$ & $\mathrm{BV}_{3}$ & $\mathrm{MH}$ \\
\hline Feb. 90 & Adults with very young chicks & $\mathrm{BV}_{3}$ & CS \\
\hline 04.03 .90 & 18 adults with 1 young & & $\mathrm{TB}, \mathrm{MC}, \mathrm{FG}, \mathrm{J}-\mathrm{CK}, \mathrm{J}-\mathrm{LV}$ \\
\hline 07.03 .90 & $30+$ adults with $1-3$ day-old chicks & & PT \\
\hline 24.11 .90 & 4 adults with 6 young, $3-4$ days old & IET & LO \\
\hline 30.12 .90 & 18 adults with 3 young, $c$. half adult size & IET & $\mathrm{HN}$ \\
\hline 20.01 .91 & c.1o adults with 4 young, c. $10 \mathrm{~cm}$ in size & IET & DF \\
\hline 24.01 .91 & c. 10 adults with 9 or 10 small young & IET & $S$ \\
\hline 29.01 .91 & 20 adults with $2+$ young, half adult size & IET & IF,NP \\
\hline 30.01 .91 & 20 adults with 4 young, $c$. half adult size & IET & IF,NP \\
\hline 06.02 .91 & 18 adults and 4 young, $1 / 2$ and $2 / 3$ adult size & IET & IF,NP \\
\hline 17.02 .91 & c. 13 adults with 4 young & IET & MEG,NP \\
\hline
\end{tabular}

May, and there was no clear relationship between the time of year and size of young birds. The number of young in flocks ranged from one to 9 or 10 , though it is very difficult to count them, especially when small. Very young birds follow the adults closely, but well-grown immatures behave more independently. The young have been described by Gatter et al. (1988); young birds we saw were all darker than the adults, with proportionately shorter necks and tails, and blackish blotches extending up the neck and onto the breast, with black also on the head. Larger immatures (e.g. 90\% of adult size) have less dark on the head than the young. There is probably a gradual reduction of the dark area on the head with age, though numerous "adults" seem to have a small diffuse dark mark on the side of the head.

No sexual behaviour was seen during the main November 1990 to February 1991 study period. However, mating was observed on 15 June 1990, at 15h21. Mating lasted for four minutes, with many attempts. After mating, the female bird shook herself, stretched one wing at a time, started feeding, and wiped her bill on the ground four times. The male also commenced feeding again immediately.

\section{Daily activity patterns and time budgets}

Dense undergrowth in many parts of the forest and the skulking behaviour of the birds made quantitative measurement of activity and time budgets difficult. It is rarely possible to see all the flock at once, to count the proportion of birds doing any one activity, such as feeding, and it is also very difficult to watch an individual bird for any length of time to record its activity over a given period. The summary below is derived from general notes based on our impressions of the activity of the birds at different times of day, and also from a limited set of timed observations of individual birds (aggregated from different flocks) throughout the day.

Our general observations showed that walking and feeding occurred throughout the day, though the percentage of time they occupied varied. In the afternoon in particular, preening appeared to take up a larger proportion of the time, and feeding less time, than in the morning. Short periods of alertness were 


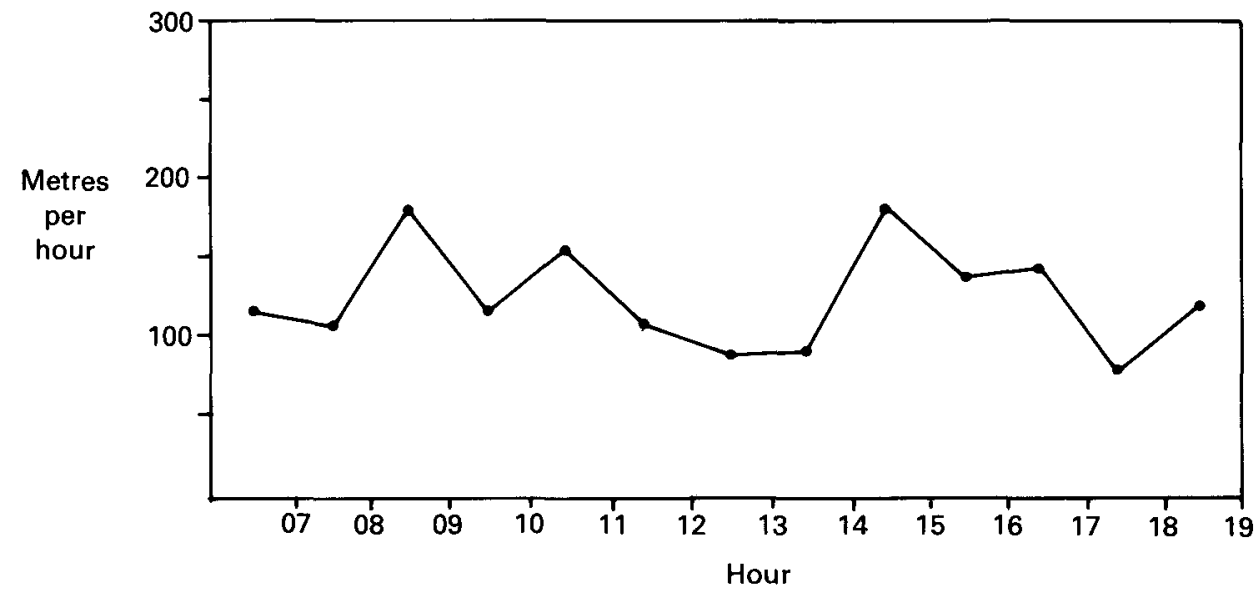

Figure 2. Average rates of movement per hour of White-breasted Guineafowl flocks in Taï Forest.

noted throughout the day, as were bouts of flying and chasing, though these latter were perhaps more frequent in the afternoon. On two occasions, an attempt was made to summarize the activity of all or most birds in a flock at different times of day. On 3 December 1990, it was considered that, during the morning, a group spent around $80 \%$ of the time feeding and $20 \%$ of the time walking (from around 1oh 45 to $12 \mathrm{hoo}$ ), but only $34 \%$ of the time feeding during the afternoon (12hoo to 17 hoo), with $29 \%$ of the time spent preening and $37 \%$ walking. On 5 February 1991, during the afternoon (13h3o to 17h47), 34\% of the time was spent preening, the remaining time feeding and walking.

In terms of activity as measured by average distance walked per hour (Figure 2), there is evidence of greater amounts of walking in mid-morning and early afternoon, and a lull in walking between around 11 hoo and 14hoo. At this time, observations suggest that birds feed quite intensively.

A total of 414 minutes (6.9 hours) of timed behavioural observations of individual birds allowed the calculation of more detailed time budgets throughout the day, using the individual observations as samples of flock behaviour. An effort was made to gather at least six minutes of timed observations in each hour of the day (10\% of each hour), which was difficult to achieve given the difficulties of watching individuals. Table 3 and Figure 3 summarize the results. It should be emphasized that these results represent only a sample of guineafowl behaviour, and some activities may be proportionally misrepresented owing to short periods of sampling, or atypical behaviour at the time. Over the day as a whole, almost $60 \%$ of the time is spent feeding, with $20 \%$ of time preening, $11 \%$ flying or in trees, and the remainder of the time divided between other activities. The $11 \%$ flying or in trees (mainly the latter) is probably an overrepresentation, but on some days birds can spend a surprising amount of time perched above the ground. The timed observations are biased towards more easily visible activities; walking and chasing, for example, by their nature mean that the bird disappears from view, and may be under-represented. From our general observations, however, the percentage breakdown of typical guineafowl 
activity for a whole day (dawn to dusk), derived from timed observations as shown in Table 3, does not seem unreasonable.

In terms of diurnal variation in behaviour, feeding activity appears to peak early in the morning, then decrease mid-morning, peak again around noon, decrease slightly in the afternoon, then perhaps increase towards dusk (Figure 3). Preening is less frequent in the early morning and around noon, but increases during the afternoon. Alertness does not show any clear pattern. Walking occupies a small percentage of the time through the day, though the

Table 3. Daily time budgets of White-breasted Guineafowl. Figures are percentages of time, for each hour centred on the time shown in left column. No data for o7hoo

\begin{tabular}{|c|c|c|c|c|c|c|c|c|c|}
\hline Time & Alert & Walk & Feed & Preen & $\begin{array}{l}\text { Flying/ } \\
\text { in tree }\end{array}$ & Chase & Inactive & $\begin{array}{l}\text { Wing } \\
\text { stretch }\end{array}$ & $\begin{array}{l}\text { Mins } \\
\text { timed }\end{array}$ \\
\hline o8hoo & 3.9 & 2.9 & 82.8 & 7.2 & 1.9 & 1.0 & & & 16.8 \\
\hline oghoo & & 3.1 & 95.5 & & 0.3 & 0.9 & & & 52.3 \\
\hline tohoo & 21.1 & 2.4 & 66.2 & 3.6 & & 1.2 & $5 \cdot 4$ & & 28.4 \\
\hline I1hoo & & 1.2 & 28.7 & 38.6 & 20.2 & 0.7 & 10.6 & & 94.2 \\
\hline 12 hoo & 3.9 & 4.3 & $67 \cdot 4$ & 10.9 & & & 13.2 & & $25 \cdot 3$ \\
\hline 13hoo & 0.9 & 8.4 & 67.1 & 6.7 & & 16.8 & & & 29.9 \\
\hline 14hoo & 4.6 & $7 \cdot 5$ & $43 \cdot 3$ & 19.7 & 18.5 & 3.1 & 2.9 & 0.4 & 16.2 \\
\hline 15hoo & 2.0 & 0.5 & 48.2 & 32.3 & 16.9 & & & & 65.0 \\
\hline $16 h o o$ & & 3.9 & 67.6 & 8.3 & 20.0 & & & & 60.0 \\
\hline 17hoo & 10.8 & 5.7 & $37 \cdot 7$ & $37 \cdot 5$ & & 8.3 & & & 10.0 \\
\hline 18hoo & 1.6 & 2.1 & 76.9 & 19.3 & & & & & 15.5 \\
\hline$\%$ of day & 2.7 & 2.9 & 58.4 & 19.2 & 11.0 & 1.9 & 3.7 & 0.02 & \\
\hline \multicolumn{8}{|c|}{ Total minutes of timed observation } & & 413.6 \\
\hline
\end{tabular}

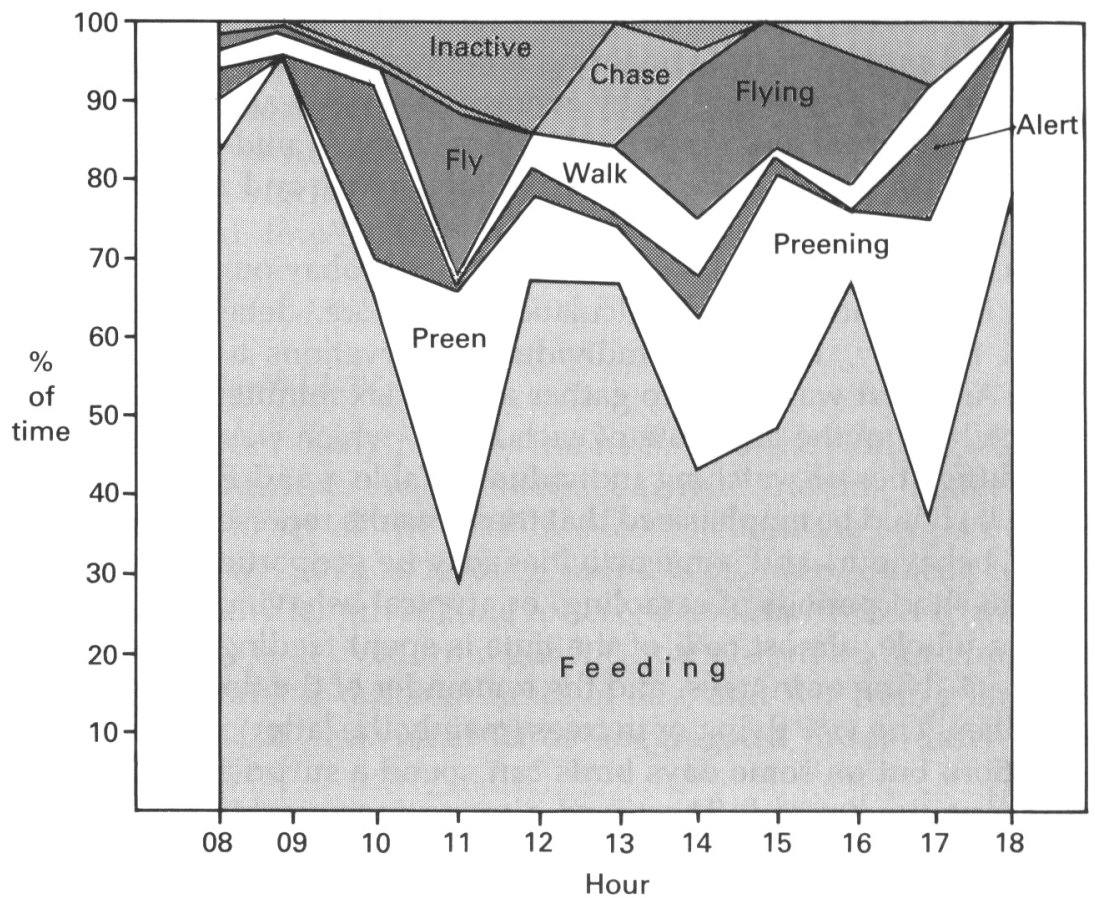

Figure 3. Daily activity of White-breasted Guineafowl in Taï Forest. 
slight increase around noon does not match the pattern of movement rates described in Figure 2. As noted above, the "walking" category does not include the slow, feeding walk (included in "feeding"), but describes more determined and longer bouts of movement. Chasing and flying into trees seem much more prevalent during the early and mid-afternoon.

\section{Group sizes, flock movements and home ranges}

The average group size for all flocks seen in Taï Forest during all phases of the Avifaunal Survey, was 15.8 (S.E.M. $=0.67, n=59$, range 5-29; definite counts only). The standard error of the mean, together with the strongly normally distributed data, means that from our sample of 59 , it is $95 \%$ likely that the true average flock size in Tai Forest lies between 14.5 to 17.1 birds per flock. It is possible, though, that group size varies throughout the year; for example, mean group size for the period May to July was 18.4 (S.E.M. $=1.1, n=11$ ), whereas for the period November to January, mean group size was significantly less at 14.5 (s.e.m. $=0.76, n=29$; Student's $t$-test: $t=2.82$, d.f. $=38, P<0.01$ ). However, Figure 4 shows mean monthly group sizes through the year for all phases of the study, utilizing definite counts only, and no clear annual trend is apparent. These data are influenced by small sample sizes in some months, and a much larger set of definite counts from every month is necessary to detect any pattern of change in flock sizes through the year.

Guineafowl groups are quite mobile, ranging over the forest in search of food. Figure 5 summarizes this information for the immediate area around the Institute d'Ecologie Tropicale (IET) station, where most sightings were made. Average rates of movement per hour were plotted for all sightings (summarized in Figure 2), and overall mean rates of hourly movement for each sighting are summarized in Table 4 .

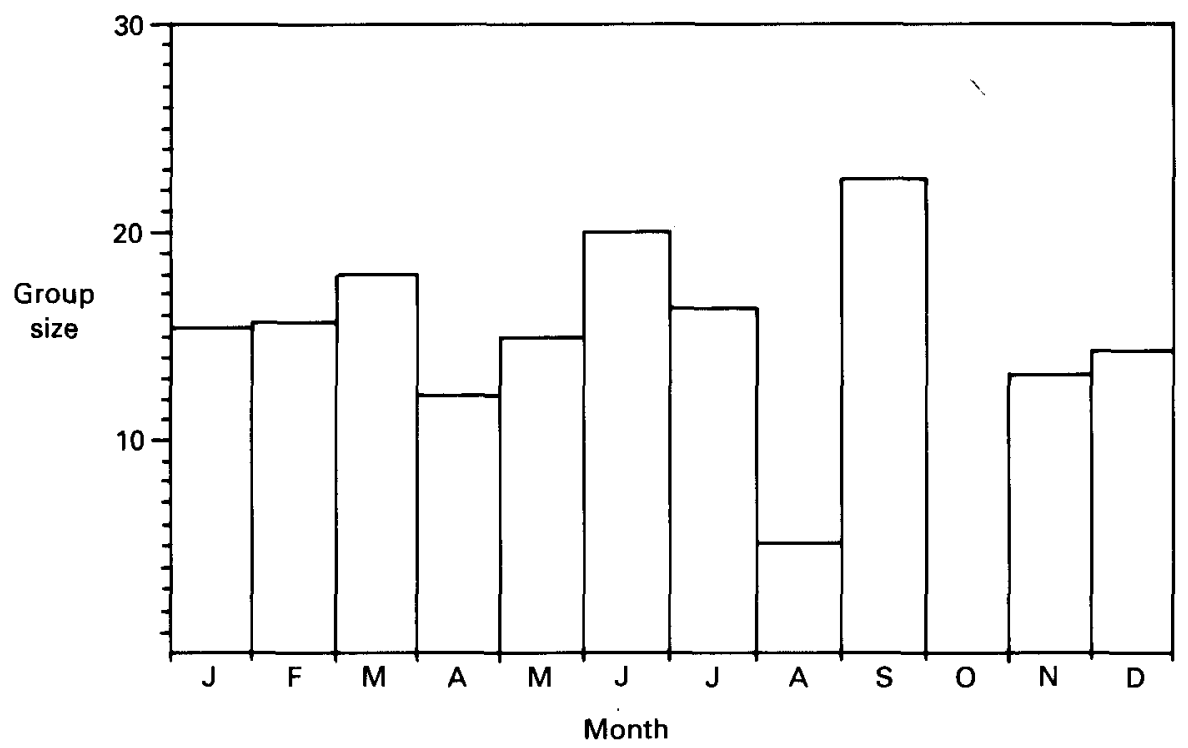

Figure 4. Monthly mean group sizes of White-breasted Guineafowl in Taï Forest, February 1989-February 1991. Sample sizes in monthly order: 10, 8, 6, 2, 2, 7, 2, 1, 2, 0, 3, 16. 


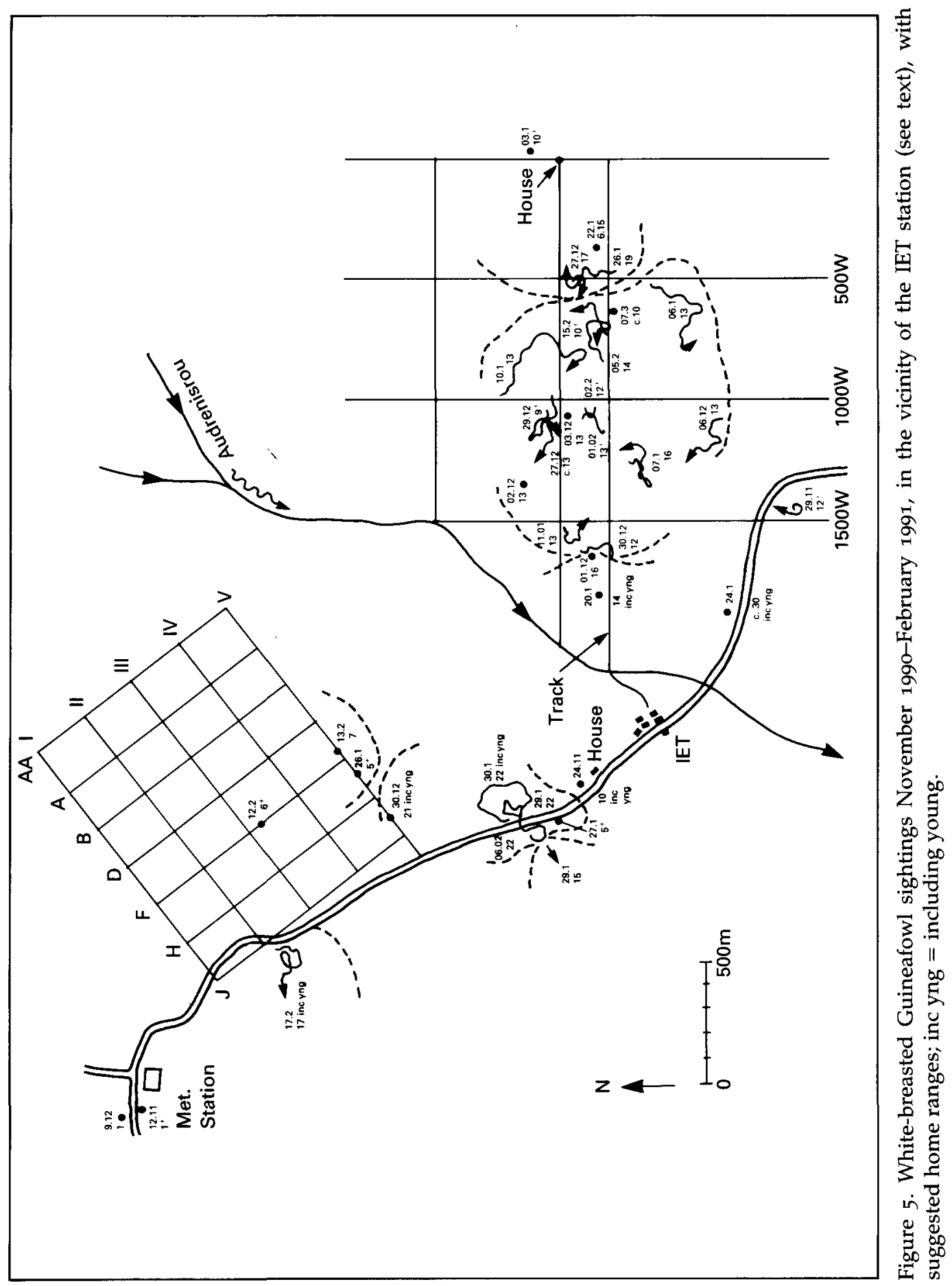


Table 4. Summary table of average distance moved per hour in each period of observation of White-breasted Guineafowl (Dec 1990 to Feb. 1991)

\begin{tabular}{lc}
\hline Date & Average hourly movement $(\mathrm{m})$. \\
\hline 05.12 .90 & 120 \\
06.12 .90 & 177 \\
20.12 .90 & 122 \\
27.12 .90 & 112 \\
27.12 .90 & 152 \\
29.12 .90 & 120 \\
30.12 .90 & 94 \\
06.01 .91 & 158 \\
07.01 .91 & 140 \\
10.01 .91 & 203 \\
11.01 .91 & 142 \\
26.01 .91 & 125 \\
29.01 .91 & 151 \\
30.01 .91 & 104 \\
01.02 .91 & 133 \\
02.02 .91 & 58 \\
04.02 .91 & 39 \\
06.02 .91 & 10 \\
15.02 .91 & 78 \\
17.02 .91 & 55 \\
\hline
\end{tabular}

Guineafowl move at an average of $115 \mathrm{~m} / \mathrm{h}$ (range $10-203 \mathrm{~m} / \mathrm{h}$ ) through the day, with evidence of higher rates of movement during mid-morning and midafternoon (Figure 2). The routes they follow are often convoluted, and though birds may (rarely) move as much as 1,200 $\mathrm{m}$ in six hours, they may finish only a short distance from where they started out.

In the absence of marked or radio-tagged birds, it is difficult to assess the home range of any guineafowl group. However, repeated sightings of groups containing the same number of birds, together with multiple sightings on the same day, boundary disputes and the presence or absence of young birds, enables some tentative estimates to be made of home ranges. Figure 5 shows some suggested group ranges, and Figure 6 shows the distribution of all guineafowl records on a grid square basis, together with suggested numbers of groups. It must be stressed that these "group area" boundaries are very tentative, and only one group was seen a sufficient number of times to be more definite about its home range. This group of 13 birds, centred on location J10 on the grid in Figure 6, probably ranged over an area of around $0.9 \mathrm{~km}^{2}$ during December to February, with other groups to the west and east. Another group of 22 birds, including young, was seen at locations $800 \mathrm{~m}$ apart, and was seen to have a "boundary dispute" with another group of 15 .

It is quite likely that group areas are not fixed, and probably overlap with others, except when two groups meet each other. Home ranges may also change in size during the year, especially if group size also changes seasonally. In the absence of more definite information, and taking account of the fact that home ranges appear close to $1 \mathrm{~km}^{2}$, it seems reasonable to assume that the "average" group of guineafowl of around 16 birds occupies a home range of approximately $1 \mathrm{~km}^{2}$. 


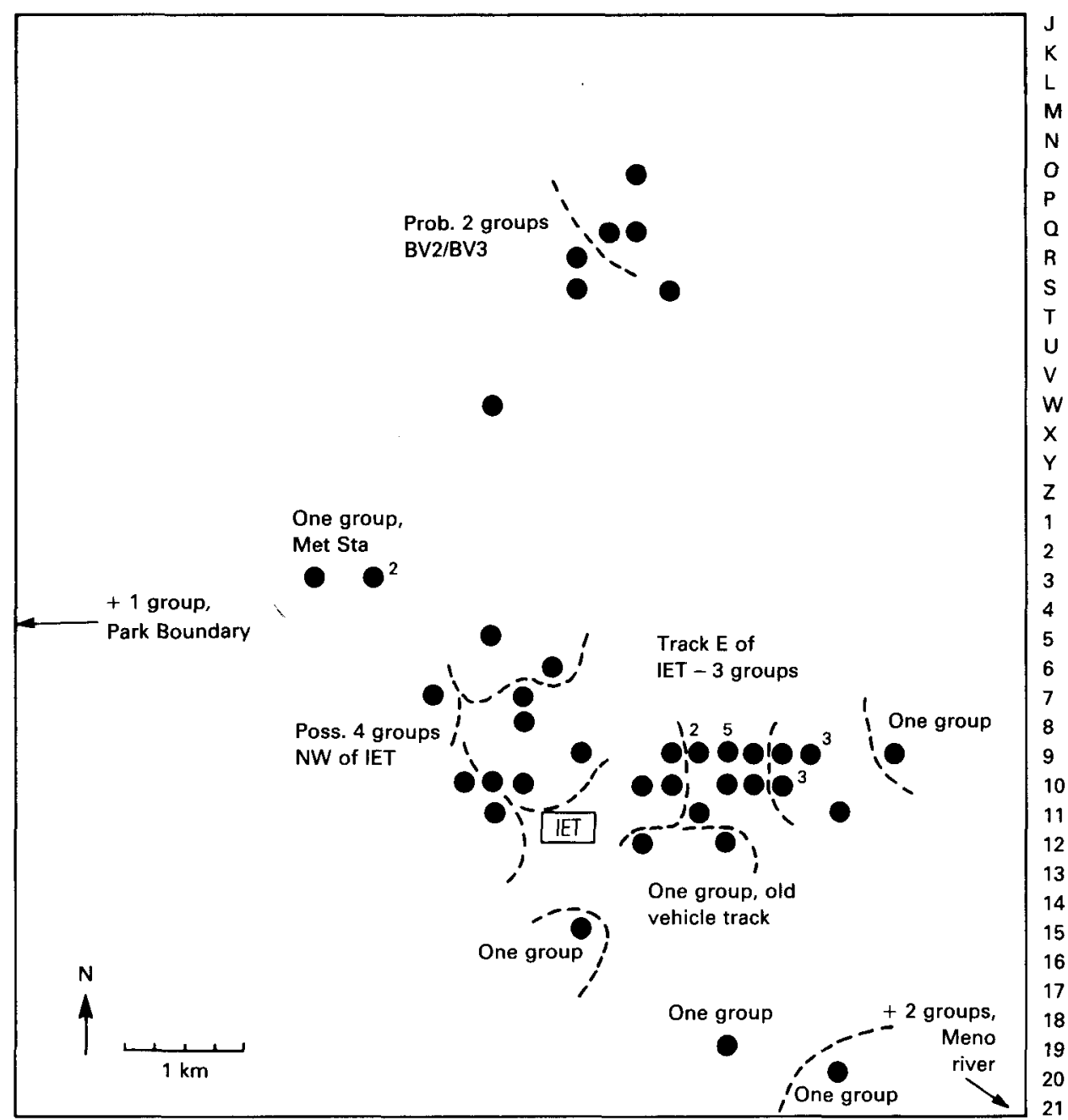

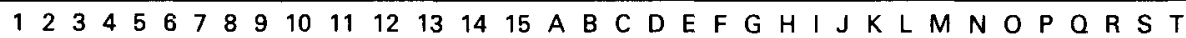

Figure 6. Locations of all White-breasted Guineafowl sightings November 1990-February 1991 within a $8 \times 8 \mathrm{~km}$ area around the IET station. Multiple sightings in one grid space are indicated.

\section{Habitat selection}

For as many foraging areas as possible, information on a number of habitat factors was recorded, mostly as estimates or subjective scales. Details are given in Table 5, together with explanation of the methods used. Originally it was intended to make more quantitative measurements of habitat factors, in a similar manner to those of Allport et al. (1989), but it soon became clear that this would not yield any fruitful results in Taï Forest. Within the dry forest, there is much variability in some habitat features, such as shade, shrub density, canopy cover, etc., but the guineafowl foraged evenly in all types of dry forest, making it difficult to detect any form of "micro-habitat" preference. This lack of clear 
Table 5. Habitat characteristics for White-breasted Guineafowl feeding areas, Tai Forest, December 1990 to February 1991

\begin{tabular}{|c|c|c|c|c|c|c|c|c|c|c|c|c|c|}
\hline \multirow{2}{*}{$\begin{array}{l}\text { Date } \\
18.12\end{array}$} & \multirow{2}{*}{$\begin{array}{c}\text { Slo } \\
5\end{array}$} & \multirow{2}{*}{$\frac{\text { Asp }}{90}$} & \multirow{2}{*}{ Sha } & \multirow{2}{*}{$\frac{\text { Wet }}{3}$} & \multirow{2}{*}{$\begin{array}{l}\begin{array}{c}\text { Soil } \\
\text { type }\end{array} \\
\text { dy loam }\end{array}$} & \multirow{2}{*}{$\frac{\begin{array}{c}\text { Dead } \\
\text { wood }\end{array}}{3}$} & \multirow{2}{*}{$\begin{array}{c}\begin{array}{c}\text { Dead } \\
\text { leaf }\end{array} \\
90\end{array}$} & \multirow{2}{*}{$\begin{array}{l}\text { Can } \\
\text { cov }\end{array}$} & \multirow{2}{*}{$\begin{array}{c}\begin{array}{c}\text { Can } \\
\text { ht }\end{array} \\
15-30\end{array}$} & Epi & \multicolumn{2}{|c|}{$\begin{array}{l}\text { Shrub } \\
\text { layer: }\end{array}$} & Sap \\
\hline & & & & & & & & & & & $1-3$ & 6 & 5 \\
\hline \multirow[t]{4}{*}{29.11} & o & 0 & 4 & 2 & Sand & 2 & 50 & $7^{\circ}$ & 15 & 0 & 3 & 5 & 10 \\
\hline & 5 & 90 & 6 & 2 & Sand & 5 & 100 & 85 & 10 & 2 & 2 & 6 & 6 \\
\hline & 3 & 180 & 4 & 3 & Sand & 1 & & 70 & 20 & 0 & 3 & 4 & 8 \\
\hline & 2 & 180 & 7 & 1 & Sand & 3 & 100 & 90 & 0 & 0 & 4 & 7 & 6 \\
\hline \multirow[t]{5}{*}{05.12} & 2 & 130 & 4 & 3 & Sand & 2 & 60 & 60 & 20 & 2 & 3 & 4 & 10 \\
\hline & 0 & 0 & 5 & 3 & Sandy laterite & 1 & 70 & 80 & 30 & 3 & & 6 & 12 \\
\hline & 5 & 90 & 6 & 2 & Sandy laterite & 2 & 80 & 95 & 20 & 1 & 1 & 7 & 6 \\
\hline & 5 & 360 & 7 & 2 & Sand & $I$ & 60 & 95 & & 0 & 0 & 7 & 4 \\
\hline & o & 0 & & & Sandy laterite & & 95 & & & & & & 15 \\
\hline \multirow[t]{2}{*}{27.12} & 3 & 180 & 6 & 2 & Sandy laterite & 3 & 80 & 85 & 10 & 1 & 1 & 5 & 7 \\
\hline & 3 & 180 & & 2 & Sandy laterite & 3 & 60 & 70 & 30 & 1 & 1.5 & 8 & 4 \\
\hline 30.12 & o & 0 & 5 & 4 & Clay bottom & 4 & 95 & & 15 & $o$ & $1+10$ & 6 & 4 \\
\hline 01.02 & 0 & 0 & 7 & 4 & Clay loam & 2 & 95 & 80 & $20+10$ & 2 & 2 & 5 & 14 \\
\hline 02.02 & 3 & 180 & $5-8$ & 2 & Sandy loam & $2-3$ & 85 & 70 & 10 & 2 & $1-2+10$ & 5 & $5-7$ \\
\hline 06.02 & 0 & 0 & 9 & 2 & Sandy laterite & 2 & 95 & 10 & 8 & 4 & 8 & 7 & 10 \\
\hline 29.01 & 3 & 270 & 8 & 2 & Sandy loam & 2 & $60-100$ & 30 & 15 & $0-3$ & $4-5$ & 8 & 3 \\
\hline 30.01 & 0 & 0 & 4 & 2 & Sand & 2 & 90 & 70 & $12+20$ & 3 & 1 & 3 & 4 \\
\hline 15.12 & 2 & 330 & 7 & 5 & Clay gravel & 3 & 80 & & & & & & \\
\hline 27.12 & & & & 2 & Sandy loam & 5 & $50-95$ & & & & & $7-10$ & $3-5$ \\
\hline 26.01 & & & & $2-3$ & Sandy laterite & & $50-90$ & & & & & & \\
\hline 04.02 & & & $4^{-8}$ & 2 & Sandy loam & $3-5$ & $80-95$ & & 10 & & & & \\
\hline 02.12 & 10 & & 8 & 3 & Sandy silt & 7 & 95 & & & & & & \\
\hline 20.12 & 5 & 90 & 5 & 4 & Clay loam & 2 & 70 & 70 & $15+10$ & 3 & 2 & 6 & 5 \\
\hline 11.12 & 3 & 300 & 6 & 0 & Sand & 4 & 70 & & & & & & \\
\hline 09.12 & & & 8 & 5 & & & & & & & & & \\
\hline 17.12 & & & 10 & 3 & Organic & 3 & 60 & & & & & & \\
\hline 26.12 & 10 & & 5 & 3 & Organic & & $50-89$ & & & & & & \\
\hline
\end{tabular}

Habitat factors estimated in field and recorded as percentages or subjective scales from 1 to 10 . Slo, estimated slope angle in degrees; Asp, overall aspect of feeding site in degrees; Sha, shade (1 = unshaded, $10=$ dense shade); Wet, site wetness $(1=$ very dry e.g. inselberg, $10=$ swamp); Soil type, general description of soil in feeding area; Dead wood, dead wood cover on ground $(0=$ none, $10=$ much); Leaf, $\%$ cover of dead leaf-litter on ground; Can cov, $\%$ canopy cover (\% of sky covered by canopy looking upwards); Can ht, approximate average height of canopy (m); Epi, epiphyte density ( $0=$ none, $10=$ many); Shrub layer ht, estimated average height of shrub layer (m); Shrub layer den, estimated density $(0=$ none, $10=$ very dense); Sap, estimated number of small saplings $(<30 \mathrm{~cm})$ per $\mathrm{m}^{2}$.

trends was also noted for Gola Forest by Allport et al. (1989). However, a more fundamental habitat selection was apparent in our study. The guineafowl appeared almost completely to avoid entering the low-lying, seasonally inundated, wetter valley bottoms (termed bas-fonds locally), which are scattered along stream courses through most of the forest. Birds were seen in such areas only five times, always for short periods, such as when crossing the valley. They were only seen to feed there three times, again for a small percentage of the observation time in each case. The wet valley bottoms were searched along with other parts of the forest when looking for guineafowl, but birds were never found there, and on several occasions they would work along the edges of these areas, and cross them rapidly, or even fly across them. 


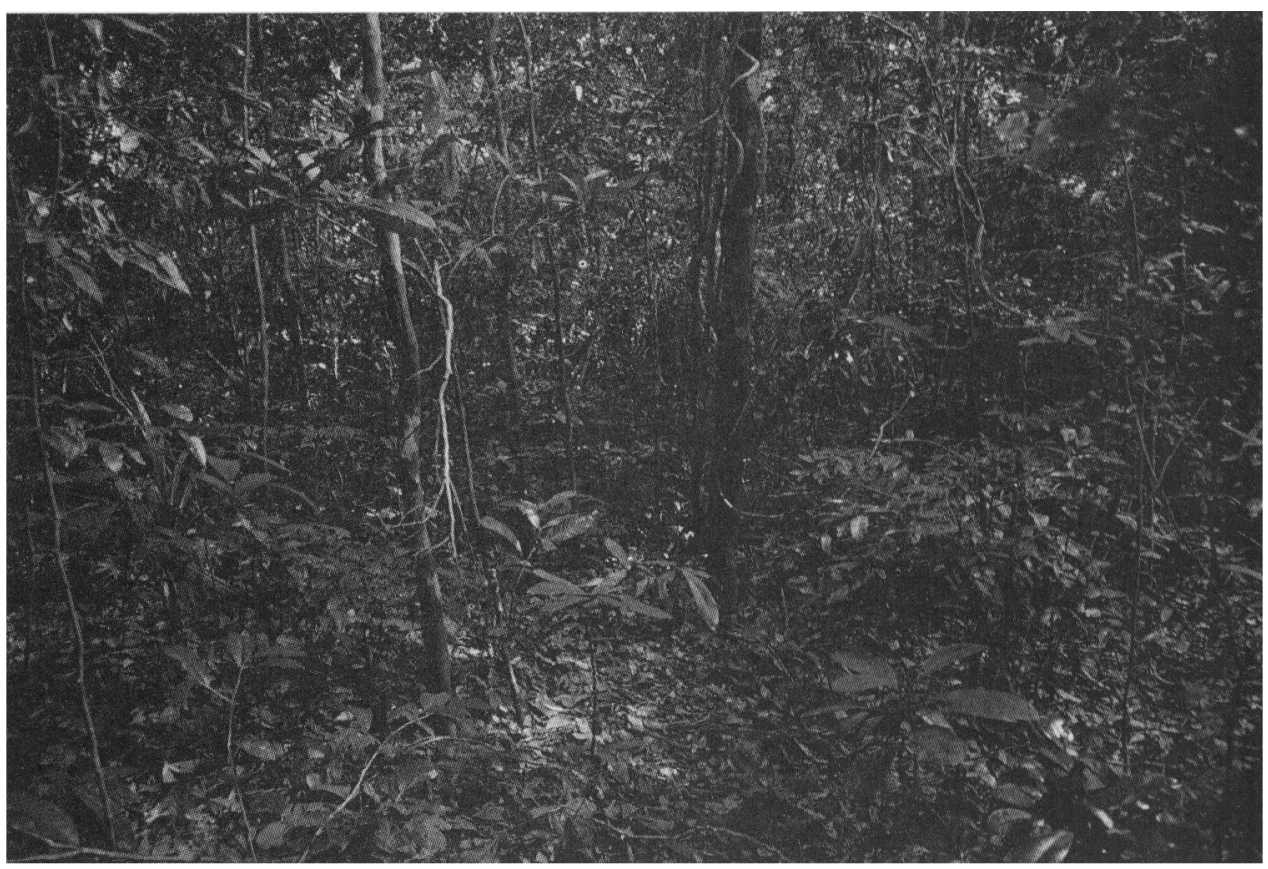

Plate 6. Dry forest.

Since guineafowl so rarely entered the wet valley bottoms, little habitat information was recorded for any feeding areas there. However, the difference between them and the dry forest is very great, and is instantly obvious in the field. Detailed information can be found in several studies of the forest (e.g. Casenave et al. 1980, Fritsch 1980, UNESCO 1984, van Reuler and Janssen 1989), but in general terms the valley bottoms are dominated by waterlogged, claydominated gley soils, and are seasonally inundated. Vegetation is dominated by species in the family Marantaceae, and frequently palms Raphia spp. Dead leaf cover on the ground is generally low, and there are many runnels and much uneven ground. It is probable that soil invertebrates and surface-living insects are scarcer, or fruit-bearing trees less common, thus providing fewer potential food sources for the guineafowl.

The dry forest areas (Plate 6) are similar in general terms across many areas of the park, varying only in small-scale features which appear not to influence the guineafowl. Slope and aspect are low or non-existent, reflecting the low-level plateau topography of much of the south-west of Côte d'Ivoire. The soil is generally dry, even in the wet season, due to rapid drainage, and the forest floor is usually quite smooth. The soil catena described by Fritsch (1980) shows that, away from the valley bottoms, slopes are characterized by sand or sandy loam soils, with laterite gravel appearing at the highest point on the interfluves. Our observations, and those of others (J. Stoorvogel pers. comm.) suggest that the guineafowl favour the sandy slope soils rather than the harder laterites, though there were exceptions to this.

Dead wood is randomly scattered through the dry forest, generally at low density, or very localized around fallen trees. The guineafowl seemed to avoid 
large fallen trees, but otherwise foraged amidst dead wood at times. Dead leaf cover is high over all of the dry forest, and although percentage cover values of between $50 \%$ and $100 \%$ were always recorded at foraging sites, the birds were judged to feed more intensively in areas with denser cover of dead leaves.

Two features which vary greatly over the forest are the degree of shade, which is related to canopy density, and the shrub layer density; both influence the growth of saplings on the forest floor. Where the high canopy is thin, the shrub layer is often dense, and where both layers are more open, saplings reach their highest density. Parts of the study area have been logged selectively in the past, and the shrub layer is dense and well-developed in many places, especially along tracks. Fallen trees also allow more sapling growth around the clearings. It was considered that none of these factors influenced the guineafowl, which fed equally in areas of forest with dense high canopy and open forest floor, and areas of dense shrubs and saplings, where the birds were virtually invisible. However, the birds were always seen under some degree of shade, with a tendency towards areas of thicker canopy cover.

Much of the forest in the peripheral zone of the national park (Figure 1 ) has been disturbed by selective removal of valuable species in the past, and understoreys are denser than in central parts, such as around the Meno river. Whitebreasted Guineafowl appear to occur at high densities in these areas of past disturbance, and also seem to be found almost to the western park boundary, where one group was seen on 15 December 1990 moving between disturbed forest remnants close to open areas of cleared agricultural land. However, they are apparently unknown from "farm bush" areas at the park edge (V. Yagnon pers. comm.), where Crested Guineafowl are more frequent.

\section{An estimate of the White-breasted Guineafowl population in Taï National Park}

Maximum potential population The overall average group size of guineafowl flocks in the study area was 15.8, and a "typical" group may range over an area of approximately $\mathrm{I} \mathrm{km}^{2}$. In order to attempt to estimate the potential population of the birds in Taï National Park $\left(3,400 \mathrm{~km}^{2}\right.$ plus $660 \mathrm{~km}^{2}$ peripheral zone= 4,060 $\mathrm{km}^{2}$ ), a calculation was made using the following assumptions: (i) the density of guineafowl in the park is roughly 16 birds per $\mathrm{km}^{2}$; (ii) this density is uniform throughout the park, including the peripheral zone; and (iii) only around $83 \%$ of the park is suitable guineafowl habitat, the remainder being wet valley bottom habitats.

Support for assumption (ii) comes from a seemingly similar observed density of birds both within the peripheral zone (which includes the IET station) and undisturbed forest (Meno river area). This assumption may, of course, be invalid, especially if hunting is a serious pressure in some peripheral areas (e.g. the eastern side towards Soubré), or if the forest structure is radically different in any areas of the park. Also, a very small proportion of the park consists of bare or sparsely vegetated inselbergs (such as Mont Nienokoué), which are unlikely to be good White-breasted Guineafowl habitat. Support for assumption (iii) comes from our evidence above, and the information on soil associations contained in the report by Development and Resources Corporation (1967).

Using the areas given above, deducting $17 \%$ wet valley bottom from each 
gives extents of suitable guineafowl habitat of $2,822 \mathrm{~km}^{2}$ in the central part of the park, and $548 \mathrm{~km}^{2}$ in the peripheral zone, thus a total of $3,370 \mathrm{~km}^{2}$ in the whole of Taï National Park. Multiplying this area by 16 birds per $\mathrm{km}^{2}$ gives an estimated maximum population in the park of 53,600 birds, although allowing for hunting pressure (see below) we would incline towards a figure between 30,000 and 40,000 as the most likely number.

A population estimate of this kind was undertaken by Allport et al. (1989) for Gola Forest in Sierra Leone. There, they estimated from observations that Whitebreasted Guineafowl densities were around $10-15$ birds per $\mathrm{km}^{2}$ in primary forest, but much lower ( 1 or 2 birds per $\mathrm{km}^{2}$ ) in "logged" forest, based on a single observation. The $10-15 \mathrm{birds} / \mathrm{km}^{2}$ is similar to the estimated density in Tai Forest, which was derived from a much larger set of observations.

The White-breasted Guineafowl population in Taï Forest is likely to be very important in world terms. The species is clearly sensitive to hunting (Allport 1991), and this is likely to be the limiting factor in areas of otherwise suitable habitat, such as Yapo Forest (Côte d'Ivoire). Hunting pressure is likely to be high in Liberian forests; Collar and Stuart (1985) report that trapping and shooting of wildlife is particularly severe there. In Tai Forest, the birds are still hunted to an unknown (but probably small) degree; according to local people hunters use the regrouping call and shoot up to 10 birds per shot. It is possible that hunting is the biggest single threat to White-breasted Guineafowl, and this factor probably reduces the likely population in Liberia considerably, where the species, though present, appears to be very rare. The population of guineafowl in any area is directly related to the area of reasonably intact forest undisturbed by hunting, and will be progressively reduced as forest loss continues. The importance of retaining intact, protected forests for the future of the birds is clear.

\section{Interactions with other species}

During the course of our guineafowl observations, notes were taken of any apparent interaction with other animals, since some possible feeding associations have been suggested previously, for example, between the guineafowl and troupes of monkeys. During the main phase of the study, we found no evidence of any such associations except in the case of some small passerines.

Chimpanzee Pan troglodytes C. and H. Boesch (pers. comm.) have observed that the guineafowl sometimes feed (on nut fragments?) at nut-cracking sites used by chimpanzees. They have also seen young chimpanzees chasing the guineafowl "for fun" (e.g. on 18 September 1989). Although we did not see the two species together during our study, this behaviour was noted by others on 26 December 1990, when a group of over 20 chimpanzees caused great alarm amongst the guineafowl, with young chimpanzees chasing the birds (P. Gagneux and P. Marchesi pers. comm.).

Duikers Cephalophus spp. We saw Maxwell's Duiker C. maxwelli on many occasions very close to the guineafowl and on at least one occasion (2 February 1991) one was feeding with them. On most occasions, however, a duiker would approach within a few metres of the guineafowl, then notice the observer, snort, 
and run off quickly. Most of the time this caused little reaction in the flock, perhaps because at certain times of year the duikers chase each other frequently and noisily, often running close to or through groups of guineafowl without causing undue disturbance. Numbers of Maxwell's Duiker are high in the forest (H. Newing pers. comm.), and this makes encounters likely, but there was no apparent feeding association, except perhaps by chance. Two Zebra Duikers $C$. zebra were also seen with one group of guineafowl during Phase IIb of the study.

Monkeys: Cercopithecus, Colobus, Cercocebus spp. We did not see any evidence of feeding associations between monkeys and the guineafowl during the main phases of the study, though this was thought to be a possibility early in the project (Gartshore 1989), and may occur at certain times of year. Monkeys were observed frequently in the general vicinity of guineafowl groups, but the birds did not noticeably move towards them. It was thought that they may feed on dislodged fruit, but this did not seem to be the case. C. Boesch (pers. comm.) has suggested that there may be a feeding association between the guineafowl and collared mangabey Cercocebus torquatus, which feed much more on the ground than other monkeys, but we did not observe this. On 2 February 1991, the guineafowl apparently delayed going to roost because a troupe of red colobus Colobus badius moved through the trees overhead.

Cusimanse Crossarchus obscurus On two occasions, this mongoose was seen with the guineafowl. On 21 May 1990, two were seen feeding c. $2 \mathrm{~m}$ away from the birds with no reaction from either species. On 30 January 1991, one ran across a guineafowl feeding area, just after the birds had walked off, possibly looking for insects on the recently disturbed ground.

African Goshawk Accipiter tachiro On 30 January 1991, a bird of this species flew low over a feeding group of guineafowl, causing panic and flying, but it did not attempt to attack any of the group.

Latham's Forest Francolin Francolinus lathami These were seen frequently close to guineafowl feeding areas, but no association was noted. The francolins feed in a similar manner to the guineafowl, possibly on similar prey.

Crested Guineafowl Guttera pucherani This species also occurs in the forest with White-breasted Guineafowl, though it is more frequently encountered in peripheral forest and farm-bush areas. We saw Crested Guineafowl much less often than the White-breasted, and only on three occasions were they together or very close. No association was noted. The two species appear to feed on similar items - see section on diet above. Bechinger (1964) noted that it is rare to see the two species mixed, though he cited one example.

Passerine birds On several occasions, species of ground-feeding or low canopy passerines were seen feeding with the guineafowl, on areas of turned-over leaves, presumably looking for unearthed insects. These included Fire-crested Alethe Alethe diademata (six times), Grey-headed Bristlebill Bleda canicapilla (twice), Brown-chested Alethe Alethe poliocephala (once), Northern Bearded 
Scrub Robin Cercotrichas leucosticta (once) and African Pitta Pitta angolensis (once: P. Taylor pers. comm.). The Fire-crested Alethe probably catches insects which fly up when disturbed by the guineafowl. African Pittas are known to follow other vertebrates.

Bird parties Occasionally, the guineafowl were seen feeding close to canopy bird parties, though no definite association was noted. Bird parties may on occasion make calls which sound very like White-breasted Guineafowl, sometimes causing confusion.

\section{Discussion and brief review of the ecology of White-breasted Guineafowl}

\section{Breeding}

The nest of the White-breasted Guineafowl has never been discovered by ornithologists, but Bechinger (1964) considered that it is likely to be made on the ground, protected by thick undergrowth, and that the eggs probably number about a dozen. However, we discussed this with V. Yagnon, whom we employed as a guide and who is very familiar with the birds. He claimed that he had seen White-breasted Guineafowl nests on two occasions, and that they were made in trees at around $15 \mathrm{~m}$ height. He said he had climbed up to investigate, and that the nests were made with sticks and lined with leaves; he had found three eggs on one occasion. It is difficult to know how reliable this record is, but it is certainly conceivable that the birds may nest in trees, despite the fact that all other guineafowl whose nests have been found nest on the ground (Crowe 1985). White-breasted Guineafowl frequently fly into trees, and are very conspicuous birds; nesting on the ground, they would be very visible to predators, in contrast to other ground-nesting galliformes which are generally well-camouflaged, particularly the females. The nest of the closely related Black Guineafowl Agelastes niger has never been found, so comparisons cannot be made. The nest of the Crested Guineafowl is made in a depression under a bush with a scanty lining of leaves or grass (Mackworth-Praed and Grant 1970, Crowe 1985). The eggs of captive White-breasted Guineafowl are said to be pale reddish-brown with white pores, about $45 \times 35 \mathrm{~mm}$ in size (Mackworth-Praed and Grant 1970).

From the observations presented above, it would seem that the breeding season may last for at least half the year, from October to May, with perhaps a peak at the end of the wet season from November to January, when there were several sightings of progressively older chicks. Numerous forest species reach a peak in their breeding season at the end of the wet season, when more food is available. However, the one record of mating was on 25 June, which may indicate that birds may breed throughout the year. White-breasted Guineafowl have young at approximately the same time as Crested Guineafowl and Latham's Forest Francolin, from our observations. Our findings correspond with those of Allport et al. (1989) for Gola Forest, Sierra Leone, where recently hatched chicks were seen in December. Balchin (1988) also noted young in December in Taï Forest. However, in both our study and the Gola study, most fieldwork was carried out between November and April/May, and the July to October period has not been properly sampled. 
It is not known whether birds are constantly paired. There were no obvious pairs within the flocks, except for a few records of brief mutual grooming, which may have indicated this. The young birds were not clearly associated with two birds, often closely following only one adult. Crowe (1985) suggests that small groups of Agelastes guineafowl may be composed of families, and Allport (1991) also suggests that they are composed of families with chicks and other adults.

\section{Feeding ecology and behaviour}

The feeding behaviour was very consistent through the study period and corresponds to observations made by Allport et al. (1989). Previous reports of guineafowl diet have been less consistent, however. Bechinger (1964) describes the diet as consisting of anything obtainable in the undergrowth, both animal and vegetable matter, with the ground beneath fruiting trees being particularly favoured. Local people have told us that the guineafowl eat termites, and it is likely that they have seen gut contents. Urban et al. (1986) describe the food taken by the birds as "insects, small molluscs, berries and fallen seeds of forest trees; captive birds readily eat termites and rice". We did not find any visual evidence of birds feeding on anything other than invertebrates, and it is possible that observations of birds feeding under fruiting trees may in fact relate to feeding on fruit flies and other insects around the fruit.

Bechinger (1964) also notes that when a bird finds food, others move in quickly in an attempt to displace it. This may occur, but our observations suggest a more complex group response to patchy food resources. When one bird discovers a richer feeding area, it often utters a "food muster" call to attract other birds to share the food. This cooperative strategy would be mutually beneficial.

Periods of feeding were interspersed with periods of resting and preening. Feeding appeared to be most intense early in the morning, when the birds first came down from roost, and continued through most of the day. There appeared to be a period during the afternoon when feeding was less prevalent, and birds spent more time preening and resting. The intensity of feeding seemed to be inversely related to the distance travelled per hour, with more rapid movements in poor feeding areas, and intense feeding where food was more abundant. Few observations on detailed feeding behaviour have been made previously.

\section{Predation}

No predation was recorded during the study, though there are a number of potential predators in Tai Forest, particularly of young birds or eggs. These include marsh mongoose Herpestes paludinosus, cusimanse Crossarchus obscurus, other mongoose species, golden cat Profelis aurata, leopard Pantherus pardus and possibly chimpanzee Pan troglodytes. Predatory birds include African Goshawk Accipiter tachiro, Great Sparrowhawk A. melanoleucus, Crowned Eagle Stephanoaetus coronatus and African Harrier Hawk Polyboroides radiatus. Roosting birds are at risk from owls, such as Shelley's Eagle Owl Bubo shelleyi. Several species of snakes, lizards, civets and squirrels could potentially take eggs or young. 
Predation was recorded in Gola Forest by Allport et al. (1989), when a radiotagged bird was predated at roost, possibly by a mongoose. The birds roost on thin branches in spindly trees, and this may provide some defence against predation, since the movements of a mammalian predator would be more easily detected. All other species of guineafowl also roost in trees (Crowe 1985).

\section{Habitat}

Collar and Stuart (1985), citing Bechinger (1964) and personal communications to them from J. M. Thiollay, suggest that the species is found only in the thin undergrowth of primary lowland forest, and that it cannot survive in the denser understorey of secondary forest; it only rarely leaves the protection of forest cover. However, Davies (1987) suggested that it may not be wholly dependent on primary forest, but needs a closed canopy. Our study suggests that the birds are able to tolerate dense understorey in lightly disturbed and/or selectively logged forest, and that they occur there at similar densities to more open forest in the centre of the park. The only other study to consider habitat was that of Allport et al. (1989), in Gola Forest. There it was noted that they occur in logged forest, but it was suggested that the population density was much lower. An analysis of habitat data collected for guineafowl feeding areas and other random locations suggested that, in Gola, the birds showed a preference for areas covered in leaves and soil, and avoided sandy areas, and dense tangles of lianas and sticks. They seemed to prefer areas with a medium density of saplings less than $30 \mathrm{~cm}$ high. However, all preferences were weak and these factors did not clearly differ between logged and unlogged forest. It is suggested that either hunting or a reduction of invertebrate populations due to desiccation may account for the possible lower density of guineafowl in the logged parts of Gola Forest.

It can be inferred from the Gola study that most observations were in dry forest, and the avoidance of the wet valley bottoms may be widespread. On Tiwai Island, Gola, there is no primary forest present, it being mostly farm-bush, swamps and thickets. The birds were present in a thin strip of $30 \mathrm{~m}$ high, closed canopy forest (Davies 1987). Densities in disturbed forest in Tai may be higher than those in Gola because the disturbance occurred longer ago, or because hunting pressure is lower in Taii. Other factors not yet identified may also be important. It is clear, though, that the guineafowl need continuous forest cover as a bare minimum. Their exact requirements in forested zones still remain to be clarified.

\section{Recommendations for further research and conservation}

\section{Further research}

There are many remaining questions about White-breasted Guineafowl biology. In particular, information on nesting is completely lacking. The nest location, structure, clutch-size, incubation and hatching periods are unknown, as are such matters as the relationship between nest location and group home range, the mating system and the relationship between breeding birds (pairs?) and the 
non-breeding flock members during incubation. These questions are extremely difficult to answer, as the difficulties of finding nests in the forest are immense. Perhaps the best way to go about this would be to employ local people to try and find nests in the period October to February.

Another major area which needs further research is the relationship between groups. To what extent do group sizes change, and to what degree is there interchange between groups? Are there non-breeding groups and groups consisting largely of breeding birds? What is the true area of home range, does it change during the year, and how do home ranges overlap with those of other groups? Answering these questions depends on marking individuals, which in turn depends on catching birds. Allport et al. (1989) have shown that it is difficult to catch White-breasted Guineafowl (mist-nets ineffective, 220 "snare days" using 55 snares to catch one bird) and, in such a highly social bird, efforts would need to be made to catch the whole group, making the task even more difficult. Radio-tracking, as employed by Allport et al. (1989), yields useful information, but again the capture of just one individual, which is then separated from the flock, may give misleading results. It is theoretically possible to catch a whole group, but the trapping structure would need to be very large. Catching a group using baiting at regular feeding sites may be a more effective method. Other ways of marking without catching, such as dye-spraying, are feasible, but difficult. However, once marked, colour-ring combinations or dye would be quite easy to see.

Further surveys of White-breasted Guineafowl are also needed. On a geographical basis, information on populations in adjacent countries is very desirable. On a habitat basis, it is also important to discover whether the birds inhabit farm-bush areas adjacent to forest to any degree, in order to be sure that forest clearance is completely detrimental. The extent to which the species occurs in plantations needs also to be determined. Some plantations have held the birds in the past, but they disappeared after road construction, logging and planting commenced. Crested Guineafowl remain in plantations, however. Further work on the effect of varying degrees of logging intensity would also be most useful. More information on hunting of the birds is also important to gather (see below).

\section{Recommendations for the conservation of the species}

The species is likely to be conserved in perpetuity if the remaining areas of intact forest continue to exist, and if the population is not subject to hunting pressure. The first of these conditions may be met, at least over part of the birds' range, since Taï Forest and Gola Forest are the subject of conservation projects supported by the respective governments. This will help to slow or stop significant forest loss, though attrition of the edges may continue. If the integrity of Taï Forest (the last large area of forest in Côte d'Ivoire) can be preserved, then this may protect over half the world population of the birds in viable numbers. In Liberia, if the political situation improves, then Sapo National Park may offer some long-term security for a large forest area, though this is very uncertain at the moment, and forests are being lost at a high rate (5\% per annum) in other 
parts of the country. The forests which hold the species in Ghana are relatively small, and it is not known whether viable populations exist there.

The other major factor influential in the survival of White-breasted Guineafowl populations is hunting. Hunting for bush meat is very widespread in all the countries considered here, and it poses a considerable threat to some species such as red colobus. Although hunters may choose to shoot duikers or monkeys, rather than waste their cartridges on the small amount of meat a guineafowl provides (as noted for Gola Forest by Allport et al. 1989), the trick of calling the birds over, or imitating leaf-scuffing (Dutson and Branscombe in prep.) and shooting many at once may make them more attractive as a quarry species. Snares are also used to catch birds (Allport 1991). Over large areas of Taï Forest, hunting pressure is quite low (at least, probably for the guineafowl), but this may not be true of other parts. It is known (C. Boesch, pers. comm.), that hunting pressure is much higher on the eastern side of the park, where commercial poaching gangs may supply bush-meat to Abidjan. A survey of hunters around all forests holding the bird may shed some light on this problem, though in Côte d'Ivoire, at least, they would be reluctant to provide information, since hunting is technically illegal. A publicity drive coupled with this, drawing attention to the rarity of the bird, may help reduce the numbers shot.

On the basis of evidence from Taï Forest, we suggest (following Collar and Stuart 1985) that the fate of the White-breasted Guineafowl is linked principally to the conservation of large areas of intact, relatively undisturbed forest such as Taii, and that such conservation should be the major priority. This would obviously also benefit all other species. Enforcement of anti-poaching laws within the forests, where applicable, is also essential. The White-breasted Guineafowl would still qualify as a very threatened Upper Guinea species (see Allport 1991), because it has only a limited distribution within the region, is found only in primary forest (which is being rapidly destroyed) and is sensitive to human activity such as hunting. It is still considered by Allport (1991) to be the most endangered bird in the Upper Guinea forests. However, if our estimates of population are correct, then, in terms strictly related to the survival of the species, there would seem to be no immediate need for a captive breeding programme as suggested by Collar and Stuart (1985), if conservation of their habitat can be ensured.

\section{Acknowledgements}

We are very grateful to the following people and organizations for their help in this study: the Ministère des Eaux et Forêts, the Minister and his staff in Abidjan and particularly M. Bonny, for providing research permission as part of the Taï Avifaunal Survey; the Institute d'Ecologie Tropicale (Dr H. Dosso), Université d'Abidjan, for the use of their research station; CSRS (Centre Suisse de Recherche Scientifique), Abidjan, and its director, Dr Liliane Ortega, for accommodation and other essential support; Centre Néerlandais, Adiopodoumé, Abidjan, and its director, Dr F. Vooren, for accommodation and reference material.

Financial and logistical support was provided by the British Ornithologists' Union, British Airways Assisting Nature Conservation programme (Rod Hall), the Fauna and Flora Preservation Society, the Percy Sladen Memorial Fund, and World Pheasant Association (Keith Howman) and the International Council for Bird Preservation (Gary Allport 
and Adam Gretton). Dr John Beer and Steve Moreby of the Game Conservancy kindly analysed guineafowl droppings. We are extremely grateful to all of these. This study formed part of Phase III of the Taï Avifaunal Survey, a project carried out within the programme of the International Council for Bird Preservation. A.J. was supported by an NSERC grant to J. Rising.

In Côte d'Ivoire, we would also like to thank the following people for fieldwork and provision of guineafowl records: the other members of the Tai Avifaunal Survey - Peter Carson, Mark Cole, Mick Green, Least Livingstone, Susan Montonen, Colin Ryall, Phil Taylor and Ken Towle, and other researchers, visitors and station staff - Thierry Bara, Mildred Beerenschott, Christophe Boesch, Hedwige Boesch, Wilco Bosma, Martine Coste, Djezia Ferdiouno, Lincoln Fishpool, Pascal Gagneux, Francois Guerguin, Kathy Holenweg, Margaret Holting, Jean-Christophe Kovaks, Paul and Natalie Marchesi, Helen Newing, Laurent Oulai, Gerhard Radl, Claudia Steiner, Jetse Stoorvogel, M. Théo Zoroa Tiekpan and his wife Suzanne, Jean-Louis Vaccon, Gerrit-Jan van Herwaarden, Sarah Wilkins, Valentin Yagnon and Clement Zont.

\section{References}

Allport, G. (1991) The status and conservation of threatened birds in the Upper Guinea forest. Bird Conserv. Internatn. 1: 53-74.

Allport, G., Ausden, M., Hayman, P. V., Robertson, P. and Wood, P. (1989) The conservation of the birds of Gola Forest, Sierra Leone. Cambridge, U.K.: International Council for Bird Preservation (Study Report 38).

Balchin, C. S. (1988) Recent observations of birds from the Ivory Coast. Malimbus 10(2): 201-206.

Bechinger, F. (1964) Beobachtungen am Weissbrust-Waldhuhn (Agelastes meleagrides) im Freileben und in der Gefangenschaft. Gefied. Welt 88: 61-62.

Casenave, A., Flory, J., Guiguen, N., Ranc, N., Simon, J. M., Toilliez, J. and Tourne, M. (1980) Etude hydrologique des bassins de Tai. Campagnes 1978-1979. Centre d'Adiopodoumé, Côte d'Ivoire: ORSTOM.

Collar, N. J. and Stuart, S. N. (1985) Threatened birds of Africa and related islands. ICBP/IUCN Red Data Book, part 1. Third edition. Cambridge, U.K.: International Council for Bird Preservation.

Collar, N. J. and Stuart, S. N. (1988) Key forests for threatened birds in Africa. Cambridge, U.K.: International Council for Bird Preservation. (ICBP Monogr. 3)

Crowe, T. M. (1985) Guineafowl. Pp. 226-267 in B. Campbell and E. Lack, eds. A dictionary of birds. Stoke-on-Trent: T. \& A. D. Poyser.

Davies, A. G. (1987) The Gola Forest Reserves, Sierra Leone: wildlife, conservation and forest management. Gland, Switzerland: International Union for Conservation of Nature and Natural Resources.

Development and Resources Corporation (1967) Soil survey of the south-west region. A report prepared for the government of the Republic of Ivory Coast. New York: Development and Resources Corporation.

Dutson, G. and Branscombe, J. (in prep.) Rainforest birds in south-west Ghana. Cambridge, U.K.: International Council for Bird Preservation (Study Report 46).

Fritsch, E. (1980) Etude pédologique et représentation cartographique à 1:50,00o d'une zone de 1600 ha, représentative de la région forestière du Sud-Ouest Ivoirien. Rapport d'élève. Centre d'Adiopodoumé, Côte d'Ivoire: ORSTOM.

Gartshore, M. E. (1989) An avifaunal survey of Tai National Park, Ivory Coast, 28 January-11 April 1989. Cambridge, U.K.: International Council for Bird Preservation (Study Report 39).

Gatter, W., Peal, A., Steiner, C. and Weick, F. (1988) The unknown immature plumages 
of the rare White-breasted Guineafowl Agelastes meleagrides. Okol. Vögel (Ecol. Birds) 10: 105-111.

Mackworth-Praed, C. V. and Grant, C. B. H. $(1970,1973)$ Birds of West Central and Western Africa. London: Longman (2 volumes).

van Reuler, H. and Janssen, B. H. (1989) Nutritional constraints in secondary vegetation and upland rice in south-west Ivory Coast. Pp. 371-382 in J. Proctor, ed. Mineral nutrients in tropical forest and savanna ecosystems. Oxford: British Ecological Society (Spec. Publ. 9)

Taylor, M. (1988) The White-breasted Guineafowl in south-east Liberia. Unpublished report to World Pheasant Association and Royal Ontario Museum.

UNESCO (1984) Recherche et aménagement en milieu forestier tropical humide: le Projet Taí de Côte d'Ivoire. Paris: UNESCO. (Notes techniques du MAB, 15).

Urban, E. K., Fry, C. H. and Keith, S. (1986) The birds of Africa. Volume II, Gamebirds to pigeons. London: Academic Press.

\section{S. FRANCIS and N. PENFORD}

Fforest, Pandy, Meidrim, Carmarthen, Dyfed SA33 5PD, U.K.

M. E. GARTSHORE

RR\#1, Walsingham, Ontario, NoE IXo, Canada

A. JARAMILLO

Department of Zoology, University of Toronto, Toronto M5S 1A1, Canada 